\title{
Copepods enhance nutritional status, growth and development in Atlantic cod (Gadus morhua L.) larvae - can we identify the underlying factors?
}

Ørjan Karlsen, Terje van der Meeren, Ivar Rønnestad, Anders Mangor-Jensen, Trina F. Galloway, Elin Kjørsvik, Kristin Hamre

The current commercial production protocols for Atlantic cod depend on enriched rotifers and Artemia during first-feeding, but development and growth remain inferior to fish fed natural zooplankton. Two experiments were conducted in order to identify the underlying factors for this phenomenon. In the first experiment (Exp-1) groups of cod larvae were fed either a) natural zooplankton, mainly copepods, increasing the size of prey as the larvae grew or b) enriched rotifers followed by Artemia (the intensive group). In the second experiment (Exp-2) two groups of larvae were fed as in Exp-1, while a third group was fed copepod nauplii (approximately the size of rotifers) throughout the larval stage. In both experiments, growth was not significantly different between the groups during the first three weeks after hatching, but from the last part of the rotifer feeding period and onwards, the growth of the larvae fed copepods was higher than that of the intensive group. In Exp-2, the growth was similar between the two copepod groups during the expeimental period, indicating that nutrient composition, not prey size caused the better growth on copepods. Analyses of the prey showed that total fatty acid composition and the ratio of phosphollipids tototal lipids was slightly different in the prey organisms, and that protein, taurine, astaxanthin and zinc were lower on a dry weight basis in rotifers than in copepods. Other measured nutrients as DHA, all analysed vitamins, manganese, copper and selenium were similar or higher in the rotifers. When compared to the present knowledge on nutrient requirements, protein and taurine appeared to be the most likely limiting nutrients for growth in cod larvae fed rotifers and Artemia. Larvae fed rotifers/Artemia had a higher whole body lipid content than larvae fed copepods at the end of the experiment (stage 5) after the fish had been fed the same formulated diet for approximately 2 weeks. 
2 Copepods enhance the nutritional status, growth and development of Atlantic cod

3 (Gadus morhua L.) larvae; can we identify the underlying factors?

5 Ørjan Karlsen ${ }^{1,2 *}$, Terje van der Meeren ${ }^{1,2}$, Ivar Rønnestad ${ }^{3}$, Anders Mangor-Jensen ${ }^{1}$, Trina F.

6 Galloway $^{4}$, Elin Kjørsvik ${ }^{5}$, Kristin Hamre ${ }^{6}$

7

8

$9 \quad{ }^{1}$ Institute of Marine Research, Austevoll Research Station, NO-5392 Storebø, Norway

$10{ }^{2}$ Hjort Centre for Marine Ecosystem Dynamics, Institute of Marine Research, PO. Box 1870,

11 NO-5817 Bergen, Norway

$12{ }^{3}$ University of Bergen, Department of Biology, PO.Box 7800, NO-5020 Bergen, Norway

$13{ }^{4}$ SINTEF Fisheries and Aquaculture, NO-7465 Trondheim, Norway

$14{ }^{5}$ Norwegian University of Science and Technology, Department of Biology, NO-7491 Trondheim,

15 Norway

$16{ }^{6}$ National Institute of Nutrition and Seafood Research, PO. Box. 2029 Nordnes, NO-5817 Bergen,

17 Norway

18

19 


\section{Introduction}

21 In aquaculture, the production of Atlantic cod (Gadus morhua) juveniles is based on indoor intensive

22 systems with start-feeding tanks supplied with temperature-controlled seawater and in which the larvae

23 are fed enriched rotifers (Brachionus spp.) at the onset of exogenous feeding. This may be followed by

24 a period of feeding with enriched brine shrimp (Artemia salinas) before the larvae are weaned onto

25 formulated feed. However, the quality of the cod juveniles achieved with this production method is

26 variable and often suboptimal. The proportion of deformed fish is often higher than when the larvae are

27 fed natural zooplankton that consists mainly of copepods (Fjelldal et al. 2009; Imsland et al. 2006).

28 Moreover, the rate of growth of larvae fed rotifers/Artemia is lower than that of larvae fed copepods

29 (Busch et al. 2010; Busch et al. 2011; Evjemo et al. 2003; Hamre et al. 2013; Imsland et al. 2006;

30 Koedijk et al. 2010; Liu and Xu 2009). Analyses of stomach content from wild caught cod larvae show

31 that an assemblage of various species and stages of copepods are the most important food items for cod

32 larvae in their natural habitat (Wiborg 1948; Last 1978).

33 It has been hypothesised that the consistent and inferior growth rates and juvenile quality of cod

34 fed rotifers/Artemia are due to suboptimal nutrition, indicated by numerous differences in the nutrient

35 content of rotifers and copepods (Hamre et al. 2008a; Hamre et al. 2013; Imsland et al. 2006;

36 Srivastava et al. 2006; van der Meeren et al. 2008; Øie et al. submitted). The dry-weight concentration

37 of protein is much higher in copepods than in rotifers, and such levels cannot easily be obtained by

38 enrichment of the rotifers (Hamre et al. 2013; Srivastava et al. 2006). Levels of essential n-3 fatty acids

39 and phospholipids are often lower in rotifers than in copepods (van der Meeren et al. 2008). However,

40 this can be improved by using high levels of $n-3$ fatty acids in the culture medium and by culturing lean

41 rotifers which contain low levels of triacylglycerol and thus have a higher ratio of phospholipids (PL)

42 to total lipids (TL) (Hamre et al. 2013). It is well known that raising the ratio of PL to TL in larval 
43 feeds enhances growth (Cahu et al. 2003). Commercial rotifer diets usually contain sufficient levels of

44 vitamins to meet the requirements of marine fish larvae, with the possible exception of vitamin D and

$45 \mathrm{~K}$, on which there are few studies (Hamre et al. 2013). However, it is possible that microminerals are

46 present in suboptimal concentrations (Hamre et al. 2008a), probably underlying part of the reduced

47 survival of larvae (Hamre et al. 2008b). To rectify these problems, new enrichment protocols have

48 been developed for some of the potentially deficient nutrients (Nordgreen et al. 2013; Penglase et al.

49 2010; Srivastava et al. 2012; Srivastava et al. 2011), which enable comparable levels in rotifers as

50 those observed in copepods to be reached. Macrominerals and most of the B-vitamins are present in

51 rotifers and Artemia at levels comparable to those observed in copepods (Hamre et al. 2013) and

52 therefore seem to be sufficient, on the basis of our current knowledge. It should be noted that the

53 rotifers' and Artemia's own metabolisms prevent the levels of some nutrients from being customised or

54 raised by enrichment procedures.

55 In addition to nutrient composition, the size and energy content of rotifers and Artemia may

56 also limit fish growth. Marine fish larvae select prey of increasing size as they grow if different prey

57 sizes are available (Hunter 1980; Kuhlman et al. 1981; Last 1978; Olsen et al. 2000; Stepien 1976; van

58 der Meeren 1991). Two groups of cod larvae were fed small or large copepods similar in size until 25

59 days post hatch (dph), but thereafter growth was faster in the larvae fed large copepods (Busch et al.

60 2011). Furthermore, feeding cod larvae large rotifers instead of small ones, with similar prey biomass

61 per tank, resulted in significantly larger larval size after just a few days of feeding (G. Øie, SINTEF

62 Fisheries and Aquaculture, pers. comm.). It is therefore possible that the methods most often employed

63 in feeding copepods to cod, e.g. increasing prey size as the larvae grow, supplies more energy to the

64 larvae than when they are fed small rotifers and Artemia, and that different prey size is the reason for

65 the observed differences in growth rates. Another possible explanation for these variations in growth 
66 are differences in feed intake caused by sensory stimuli, due to species-specific prey movements or 67 release of chemically mediated attractants (van der Meeren 1991; Yacoob et al. 2004).

The purpose of the present study was to identify the underlying mechanisms that lead to

69 differences in the growth and development between cod larvae fed rotifers/Artemia and those fed

70 copepods. We used state-of-the-art cultivation and enrichment methods for rotifers and Artemia, while

71 copepods were harvested from a local semi-controlled seawater pond system (Naas et al. 1991; van der

72 Meeren et al. 2014). We conducted two experiments. In the first experiment (Exp-1), two groups of

73 cod larvae in triplicate tanks were fed rotifers/Artemia or copepods. Here we present data that cover

74 larval growth and survival and the nutritional status of the prey types and the developing cod larvae.

75 Additional results describing the ontogeny of cod larvae, data for transcriptomics, microRNA-

76 sequencing and metabolomics, and a wide range of biological processes in the larvae will be reported 77 elsewhere.

78 The second trial (Exp-2) was designed to distinguish between prey size and prey nutrient 79 composition as the cause of the enhanced growth of cod larvae fed copepods. Two groups of larvae 80 were subjected to the same feeding regimes as in Exp-1, i.e. one with increasing copepod size (from 81 nauplii to copepodids) as the larvae grew, and another with rotifers from the onset of first-feeding 82 followed by Artemia. Additionally, a third group of larvae were fed small prey size (copepod nauplii) 83 throughout the whole experiment. We hypothesised that similar growth rates in larvae fed small and 84 increasing sized copepods respectively, indicate that nutritional differences between rotifers/Artemia 85 and copepods is the main reason for differences in larval growth. 


\section{Material and methods}

\section{Fish material and experimental design}

90 This study was carried out within the Norwegian animal welfare act guidelines, in accordance with the

91 Animal Welfare Act of 20th December 1974, amended 19th June, 2009, at an facility with permission

92 to conduct experiments on fish (code 93) provided by the Norwegian Animal Research Authority

93 (FDU, www.fdu.no). The first trial was assumed to be a nutrition trial not expected to harm the

94 animals, no specific permit was required under the guidelines. The second experiment was approved by

95 FDU, FOOTS ID 5448.

96 Fertilized eggs for Exp-1 were obtained from Atlantic cod broodstock of coastal origin, western

97 Norway, which were held at the Institute of Marine Research (IMR), Austevoll Research Station. The

98 naturally spawning fish, 45 females and 25 males, were kept in a tank of seawater (yearly means;

99 temperature: $7.9 \pm 0.3^{\circ} \mathrm{C}$, salinity: $\left.34.7 \pm 0.2 \mathrm{~g} \cdot \mathrm{L}^{-1}\right)$. The eggs were collected overnight March 15,2012 ,

100 using an egg collector as described by van der Meeren \& Lønøy (1998). Mean egg diameter was 1.29

$101 \mathrm{~mm}$, and fertilization rate was $79 \%$.

102 Eggs for Exp-2 were obtained from siblings of the broodstock used in Exp-1, kept at sea in net

103 pens at the IMR facility in Parisvannet, Øygarden. Eggs were stripped on April 4, 2013 from three

104 females (1.2 L in total), and fertilized with mixed milt from 10 males. Sea temperature at time of

105 stripping was $4.0^{\circ} \mathrm{C}$. The fertilized eggs were immediately transported for about three hours by car to

106 IMR-Austevoll in a 151 closed plastic bag with an air space, held in a polystyrene box. On arrival at

107 Austevoll, the temperature had risen to $4.7^{\circ} \mathrm{C}$. The eggs were disinfected using $400 \mathrm{mg} \cdot \mathrm{L}^{-1}$

108 glutaraldehyde for $8 \mathrm{~min}$. according to Harboe et al. (1994). Mean egg diameter was $1.30 \mathrm{~mm}$, and

109 fertilization rate was $86 \%$. 
Water for the Austevoll station is pumped from a depth of $168 \mathrm{~m}$, sand-filtered, temperature-

111 adjusted and aerated before it enters the tanks. The eggs were held in $70 \mathrm{~L}$ black polyethylene

112 incubators with conical bases; $1 \mathrm{~L}$ of eggs per tank in Exp-1, and $0.20 \mathrm{~L}$ in Exp-2. The tanks had gentle

113 aeration (van der Meeren \& Lønøy 1998), water supplied at $0.5 \mathrm{~L} \cdot \mathrm{min}^{-1}$, 5.8-6.1 ${ }^{\circ} \mathrm{C}$, and with

114 continuous light. Dead eggs were removed daily and measured volumetrically. In Exp-1, 50\% hatching

115 (day 0) was reached on $8^{\text {th }}$ of April while in Exp-2, 50\% hatching on the $18^{\text {th }}$ of April. In both

116 experiments cod larvae were transferred to start-feeding tanks on $4 \mathrm{dph}$.

117 In Exp-1, 50000 cod larvae were stocked in each of the six black PEH 500 L start-feeding

118 tanks with gentle aeration, in order to prevent feed organisms and larvae from clogging the sieves.

119 Larvae in three of the tanks (randomized) were fed copepods, while in the other three tanks, they were

120 first-fed enriched rotifers followed by enriched Artemia. Water flow was increased with age, from 1

$121 \mathrm{~L} \cdot \mathrm{min}^{-1}$ initially to $6 \mathrm{~L} \cdot \mathrm{min}^{-1}$ at weaning, and further to $10 \mathrm{~L} \cdot \mathrm{min}^{-1}$ at experiment termination, giving a

122 water exchange rate of 32 tank volumes $\cdot$ day $^{-1}$ (van der Meeren et al. 2011). The temperature was

123 gradually increased from $8{ }^{\circ} \mathrm{C}$ at transfer to $11.6^{\circ} \mathrm{C}$ at $11 \mathrm{dph}$ (Fig. 1), where it was kept for the rest of

124 the experiment. Salinity was constant at $34.7 \pm 0.2 \mathrm{~g} \cdot \mathrm{L}^{-1}$. The tanks were equipped with air skimmers to

125 remove any biofilm on the water surface. An automated cleaning arm (van der Meeren et al. 1998),

126 rinsed the bottom of the tanks as needed from $12 \mathrm{dph}$. To modify the visual feeding environment and

127 enhance feeding (Naas et al. 1992; van der Meeren et al. 2007), $10 \mathrm{ml}$ algal paste (Marine microalgae

128 concentrate, Nannochloropsis sp., Instant Algae ${ }^{\circledR}$, Nanno 3600, Reed Mariculture, Campell, CA,

129 USA) was added to each tank 15 minutes prior to each meal until 36 dph (Fig. 2). A 16L:8D

130 photoperiod was employed, with 30 min simulated twilight at each dusk and dawn. The light source

131 consisted of two $20 \mathrm{~W}$ tungsten halogen light bulbs (12V) over each tank that provided 300-500

$132 \mu \mathrm{W} / \mathrm{cm}^{2}$ at the water surface (IL 1400A photometer, International Light Inc., Boston, MA, USA). 
134 tanks at $4 \mathrm{dph}$. Three feeding regimes were employed; larvae in four tanks received enriched rotifers

135 followed by enriched Artemia, another four tanks received copepod nauplii and copepodids with prey 136 whose size increased with larval age, and the last four tanks were given copepod nauplii without 137 increases in prey size through the larval period (Fig. 3).

138 The tank design and setup employed in Exp-2 were miniatures of the tanks in Exp-1, but 139 without cleaning arm and surface skimming. Cleaning was done manually by siphoning the bottom 140 when necessary. Water quality was similar to Exp-1, except that the water was not temperature141 adjusted. The temperature therefore ranged between 7.1 and $8.6^{\circ} \mathrm{C}$ (Fig. 1). The water flow was kept 142 stable at $0.42 \mathrm{~L} \cdot \mathrm{min}^{-1}$ during the experiment. Oxygen saturation was not measured as the daily water143 exchange rate was high relative to tank size (Fig. 1). Illumination was provided by broad-spectrum 144 fluorescent light tubes (Phillips 965 TL-D 90 De Luxe Pro) providing 200-300 $\mu \mathrm{W} / \mathrm{cm}^{2}$ at the water 145 surface. Algal paste (3.3 $\mathrm{mL} \cdot \operatorname{tank}^{-1}$, Nannochloropsis sp., Reed Mariculture) was added 15 min prior to 146 every feeding from 4 to 33 dph (Fig. 3).

\section{Larval feed and feeding regimes}

149 In Exp-1, the cod larvae were fed three times a day (09:45, 15:15 and 19:00). The rotifer cultures were 150 seven-day-old batch cultures, kept in $2 \mathrm{~m}^{3}$ conical tanks at $24{ }^{\circ} \mathrm{C}$ at densities ranging between 850 and 1512600 rotifers $\cdot \mathrm{mL}^{-1}$, and fed four times hour $^{-1}$. The diet consisted of dry baker's yeast $(0.11-0.18$

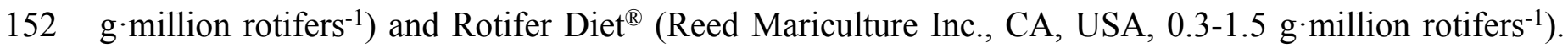
153 The rotifers were enriched before they were fed to the larvae. The enrichment protocol was performed 154 daily by moving the desired number of rotifers into an enrichment tank at densities in the range of 155 1000-2000 rotifers $\cdot \mathrm{ml}^{-1}$. The culture was given $0.6 \mathrm{mg}$ Sel-Plex ${ }^{\circledR}$ (Alltech, Vejle, Denmark) and $0.2 \mathrm{~g}$ 
156 Larviva Mulitigain (Biomar, Trondheim, Norway) per million rotifers over a 20 minute period each 157 hour from 12:00 to 08:00 the following day. After enrichment the culture was rinsed in clean $24{ }^{\circ} \mathrm{C}$ 158 seawater, then cooled to the same temperature as the start-feeding tanks, and finally stored under 159 moderate aeration and continued cooling until given to the cod larvae. From 32 to 35 dph the rotifers 160 were gradually replaced with enriched Artemia, which were fed until $63 \mathrm{dph}$. The Artemia were 161 hatched from SepArt cysts (INVE Aquaculture, Dendermonde, Belgium), and enriched at densities of 162 maximum 500 Artemia $\mathrm{mL}^{-1}$ using $0.2 \mathrm{~g}$ Larviva multigain $\cdot \mathrm{L}^{-1}$ tank volume, given four times from 163 20:00 to 08:00. After enrichment, the Artemia were rinsed in clean seawater, cooled, and stored like the 164 rotifers. From 58 to 63 dph, Artemia were fed to the cod larvae only once a day at 15:15. Weaning to 165 the formulated diet AgloNorse ${ }^{\circledR} 400-600 \mu \mathrm{m}$ (Tromsø Fiskeindustri AS, Tromsø, Norway) started by 166 hand feeding on $55 \mathrm{dph}$, and continued using feeding automats from 57 dph (Fig. 2a).

167 Copepods were collected from "Svartatjern", a nearby $25000 \mathrm{~m}^{3}$ sea-water pond system (Naas 168 et al. 1991). Pond operation, hydrographical and biological monitoring, and copepod filtration system 169 and harvest procedures are described in detail by van der Meeren et al. (2014). A UNIK-900 wheel 170 filter (Unik Filtersystem AS, Os, Norway) was used to fraction, concentrate and harvest the copepods. 171 The filter fractions used in Exp-1 (Fig. 2b) were 80-150 $\mu \mathrm{m}$ (4-11 dph), 80-180 $\mu \mathrm{m}$ (11-18 dph), 80$172212 \mu \mathrm{m}(18-23 \mathrm{dph}), 80-250 \mu \mathrm{m}(23-36 \mathrm{dph})$, and 80-350 $\mu \mathrm{m}$ (37-44 dph). The collected copepods 173 were concentrated under aeration by a $80 \mu \mathrm{m}$ plankton net and transported in a $10 \mathrm{~L}$ bucket with lid 174 and aeration for 7 min by boat to the larval rearing facility. On arrival, the concentrated mixture of 175 copepods was diluted to $30-60 \mathrm{~L}$ with $7-8{ }^{\circ} \mathrm{C}$ seawater and stored under the same conditions as the 176 enriched and cooled rotifers and Artemia. Viability was checked under a 40X magnification binocular 177 microscope. Copepods were harvested from the pond one to three times a day, depending on larval 178 needs and plankton availability in the pond. The quantities of copepods added to the larval tanks are 
179 shown in Figure 2b. The larvae were weaned to a formulated diet from $37 \mathrm{dph}$ as described above. At $18070 \mathrm{dph}$, AgloNorse was switched to Gemma Diamond ${ }^{\circledR} 1.0$ (Skretting, Stavanger, Norway).

181 In Exp-2, larvae in four tanks were fed rotifers and Artemia, which were produced as in Exp-1.

182 Rotifers were used from 4 to 34 dph, while Artemia were used from 34 to 47 dph (Fig. 3a). The

183 copepods were also obtained as described in Exp-1. The four tanks with larvae fed copepods which 184 increased in size with larval age were given the $80-150 \mu \mathrm{m}$ fraction from 4 to $15 \mathrm{dph}, 80-180 \mu \mathrm{m}$ from 18516 to $27 \mathrm{dph}, 80-212 \mu \mathrm{m}$ on 28 to $34 \mathrm{dph}$, and 212-250 $\mu \mathrm{m}$ from $35 \mathrm{dph}$ and onwards (Fig. 3b). Finally,

186 larvae in the four tanks given small sized prey only were fed copepod nauplii collected from the 80-150 $187 \mu \mathrm{m}$ fraction from 4 to $15 \mathrm{dph}$ and $80-180 \mu \mathrm{m}$ for the rest of the experiment (Fig. 3c). Exp-2 was 188 terminated on $47 \mathrm{dph}$. To measure copepod size, samples were fixed in 1:50 Lugol's solution. Samples 189 taken in the morning and afternoon on four days were photographed with two images per sample 190 (Leica MS5 with a Olympus DP70), and the total length of all nauplii and the prosome length of all 191 copepodids on the images were measured using ImageJ (v2013-2, National Institute of Health, 192 Bethesda, Maryland, USA).

194 Larval sampling and staging

195 Due to the unequal growth of the larvae in the different dietary groups, the dates of sampling in Exp-1 196 were adjusted according to larval size rather than age. Before the trial, a system of stages was 197 developed, which was based on the sequence of mineralisation of craniofacial bones and is correlated 198 with certain ranges of standard lengths (Dr. Ø. Sæle, NIFES, pers. comm). Here we report data from 199 larval stages 0-5 and juveniles. Sampling at stages 0, 1, and 2 corresponds to 4, 11 and 22 dph for both 200 groups since the growth rate was similar in the early stages. For stages $3,4,5$ and juveniles the time for 201 sampling corresponds to $28,36,52$ and $73 \mathrm{dph}$ in the copepod groups and 30,53, 70 and $84 \mathrm{dph}$ in the 
202 rotifer groups (Table 1). Additional samples for growth measurements were collected in between these 203 ages. The samples were collected two hours after the first meal of the day in order to standardise gut 204 filling conditions. The reason for sampling larvae with a full gut was that parallel samples were taken 205 for studies of digestive physiology, the results of which are reported elsewhere. The time of feeding 206 prior to sampling was adjusted to keep a fixed standardized time between feeding and sampling for all 207 tanks. Larvae used for length and dry weight analysis were individually sedated, photographed, killed 208 with an overdose of MS 222, rinsed in filtered distilled water, laid in pre-weighed aluminium beakers, 209 and freeze-dried. The beakers with larvae were weighed, and larval weight determined by subtraction.

210 Larval standard length, from the tip of the snout to the end of the notochord, was measured on the 211 photographs. At the two last samplings for each of the groups, larval length and wet weight were 212 measured. Larvae used for analysis of nutrient composition were sampled at stages 3 (at the end of the 213 rotifer period) and 5 (both groups were weaned after sampling at stage 4). Pooled larvae (one sample 214 per tank) were killed by an overdose of MS 222 and sieved through a plankton filter which was 215 subsequently patted dry from underneath with a paper towel. Samples were distributed to tubes for the

216 different nutrient analyses, immediately frozen on dry ice, and then transported to National Institute of 217 Nutrition and Seafood Research (NIFES) and stored at $-80^{\circ} \mathrm{C}$ until analyses.

218 Exp-2 was basically a growth and survival study, and larval samples were taken for weight and 219 length only, using the protocol described above. The larvae were not staged and the samples were 220 taken at the same ages for all groups.

\section{Sampling of live prey for chemical analyses}

223 In Exp-1, three samples of enriched rotifers and two samples of enriched Artemia were taken for 224 analysis of nutritional composition. The samples were taken from the cooling tanks, washed in fresh 225 water, sieved and patted dry from underneath the sieve with a paper towel, frozen and stored at $-80^{\circ} \mathrm{C}$ 
226 until analysed. The samples were filtered on a $60 \mu \mathrm{m}$ plankton net, patted dry with a paper towel, 227 frozen immediately at $-80^{\circ} \mathrm{C}$ and stored until analysis.

228 In Exp-2, rotifers were sampled on 13 and $27 \mathrm{dph}$, Artemia just after the experiment ended, and 229 small and large copepods just before first-feeding and at 6 and $21 \mathrm{dph}$.

\section{Biochemical analysis}

The nutrient composition of fish and diets was measured by ISO-certified routine methods at NIFES. Table 2 presents an overview over the biochemical methods with analysis principles and 234 references. Protein is given as Nx6.25 for cod larvae, Nx4.46 for rotifers and Nx5.30 for Artemia and 235 copepods, respectively (Hamre et al. 2013).

\section{Data analysis and statistical analysis}

238 Specific growth rate (SGR) and daily length increment (DLI) were calculated according to Ricker 239 (1979):

$240 \quad$ SGR $\left(\% \cdot\right.$ day $\left.^{-1}\right)=100 \cdot\left(\mathrm{e}^{\mathrm{g}}-1\right)$, where $\mathrm{g}=\left(\operatorname{lnW}_{2}-\operatorname{lnW}_{1}\right) \cdot\left(\mathrm{t}_{2}-\mathrm{t}_{1}\right)^{-1}$

241 DLI $\left(\mathrm{mm} \cdot\right.$ day $\left.^{-1}\right)=\left(\mathrm{L}_{2}-\mathrm{L}_{1}\right) \cdot\left(\mathrm{t}_{2}-\mathrm{t}_{1}\right)^{-1}$

$242 \mathrm{~W}_{2}$ and $\mathrm{W}_{1}$ are dry weights, while $\mathrm{L}_{2}$ and $\mathrm{L}_{1}$ are lengths at times $t_{2}$ and $t_{1}$, respectively.

243 Differences in survival between the two treatments in Exp-1 were compared using Mann-Whitney U 244 test, while the three treatments in Exp-2 were compared using Kruskal-Wallis ANOVA. Size (length, 245 weight) was compared using nested two-way ANOVA (treatment, time) with tanks nested under 246 treatment, followed by a Tukey HSD test if significant if $\mathrm{p}<0.05$. Growth rates (SGR and DLI) were 247 compared for separate stages. In Exp-1 compared by means of Student's t-test, and in Exp-2 by a one248 way ANOVA and if significant $(\mathrm{p}<0.05)$ followed by Tukey HSD. 
The data on the nutrient composition of the feeds were first checked for homogeneous variances

250 using Levene's test and log transformed if significant, using the Statistica software package (ver. 12,

251 StatSoft Inc. Tulsa, OK). They were then analysed by ANOVA and Tukey HSD test for unequal

252 sample sizes. Nutrient composition of larvae in Exp-1 on stages 3 and 5 were analysed by t-tests.

254 Results

\section{Survival}

256 In Exp-1, between 4223 and 6210 larvae were collected from each of the tanks at the end of the trial.

257 Estimates of survival, calculated as the proportion of the larvae counted out of the tanks at termination,

258 divided by the number of larvae added to the tanks at start (after sampling at $4 \mathrm{dph}, \mathrm{N}=50000$ )

259 corrected for samplings $(\mathrm{N}=10000)$, ranged between 11 and $16 \%$. Mean $( \pm \mathrm{SD})$ survivals were $14 \pm$

$2602 \%$ and $12 \pm 1 \%$ in the copepod and the rotifer/Artemia fed groups, respectively, and were not

261 significantly different between the treatments (Mann-Whitney U-test, $\mathrm{p}=0.190$ ).

262 Estimated survival at the end of Exp-2, calculated as above, ranged from 10 to $47 \%$. Mean

263 survival was lower in the group fed rotifers/Artemia (13\%, range 10-20\%) than in the small copepod 264 (39\%, range 35-47\%) and large copepod (37\%, range 31-43\%) groups (Kruskal-Wallis ANOVA, p < 265 0.001). The large and small copepod groups did not differ (Mann-Whitney U-test, $\mathrm{p}=0.837$ ).

267 Growth

In Exp-1 the larvae were $4.13 \pm 0.12 \mathrm{~mm}(\mathrm{~N}=25)$ at hatching, and $4.46 \pm 0.18 \mathrm{~mm}(\mathrm{~N}=24)$ at 4 269 dph (Stage 0). The growth in weight and length, DLI and SGR of larvae in Exp-1 were not 270 significantly different between the groups at stages $0-2$, from 4 to 22 dph (Figs. 5a and c, Table $3 a$ ). 271 The copepod group displayed significantly improved DLI and SGR compared to the intensive group 
272 between stages 2 and 4 (t-test, $p<0.01$ ), while there were no significant differences from stages 4 to 5

273 or 5 to juvenile in length increment or growth rate (Fig. 5a and c, Table 3a).

274 In Exp-2, the larval dry weight at 4 dph was $0.083 \pm 0.024 \mathrm{mg}$ and length $4.51 \pm 0.21 \mathrm{~mm}$ (Fig. $5 \mathrm{~b}$

275 and d). Mean length and weight did not differ between the treatments until 20 dph (nested ANOVA, $p$

$276>0.935)$. Thereafter, both copepod groups were significantly longer and heavier than the intensive

277 group (nested ANOVA, $\mathrm{p}<0.005$ ). No significant differences in length were observed between larvae

278 of the two copepod treatments (nested ANOVA, $\mathrm{p}>0.398$ ) except at $40 \mathrm{dph}$, when the group fed large

279 copepods was significantly longer than the group fed small copepods $(\mathrm{p}<0.001)$. Similarly, there were

280 no significant difference in dry weights between the two copepod groups except at days 40 and 47 ,

281 where the larvae fed the large copepods had higher dry weights than those fed the small copepods $282(\mathrm{p}<0.015$, Fig. $5 b$ and $d)$.

283

284 dph (Table 3b). Thereafter (days 20-34 dph and days 34-47 dph), growth was slower in the intensive 285 group, particularly during the last period, when the SGR of the intensive group fell to only half of the 286 previous period (from 8.9 to $4.4 \% \cdot$ day $^{-1}$ ) (Table $3 \mathrm{~b}$ ). There were no significant differences in DLI or 287 SGR between the two copepod groups (Mann-Whitney U-test, $\mathrm{p}>0.15$ ).

289 Prey size and nutrient composition of live feed organisms and cod larvae

290 The nauplii had overall lengths of 60 to $225 \mu \mathrm{m}$, while the copepodids had prosome lengths of 225 to $291660 \mu \mathrm{m}$ with little overlap (Fig. 4). Rotifers typically have a lorica length of 100-200 $\mu \mathrm{m}$ and Artemia 292 instar I about $4-600 \mu \mathrm{m}$.

The nutrients present at lower levels in rotifers than in copepods in Exp-1 were protein 294 ( $<<0.001)$, taurin $(\mathrm{p}<0.001)$, astaxanthin $(\mathrm{p}<0.001)$, iodine $(\mathrm{p}<0.05)$ and zinc $(\mathrm{p}<0.001)$ (Table 4). 295 There were also differences in fatty acid composition, in that the rotifers' ARA fraction $(\mathrm{p}<0.0001)$ 
296 was higher than in copepods and EPA was lower $(\mathrm{p}<0.01)$. Furthermore, copepods had a higher ratio of

297 phospholipids (PL) to total lipid (TL) than rotifers $(p=0.01)$. DHA, the lipid level measured as total

298 fatty acids, all the vitamins analysed, as well as manganese, copper and selenium were higher or

299 similar in rotifers than in copepods. The Artemia had a lower protein content than copepods $(\mathrm{p}<0.001)$,

300 similar to that in rotifers, and were characterized by taurine levels between those in rotifers and

301 copepods (different to both, $\mathrm{p}<0.01$ ), high levels of cantaxanthin, no astaxanthin, and higher average

302 levels of vitamin $\mathrm{C}, \mathrm{E}$ and $\mathrm{K}(\mathrm{p}<0.01)$ compared to copepods. Iodine $(\mathrm{p}=0.02)$ and zinc $(\mathrm{p}<0.001)$

303 levels were lower in Artemia than in copepods. The fatty acid composition was characterized by

304 similar DHA levels, but a much higher EPA:ARA ratio in copepods compared to Artemia. The level of

305 total fatty acids and the ratio of PL to total lipids were similar to that in copepods.

306 The levels of selected nutrients in cod larvae fed rotifers/Artemia or copepods in Exp-1 were

307 analysed at stages 3 and 5. Dry matter (DM) and protein did not differ between larvae fed the two diets

308 (Table 6). At stage 3, taurin was almost 20 times as high in larvae fed copepods as in those fed

309 rotifers/Artemia (40 and $2.1 \mu \mathrm{mol} \cdot \mathrm{g}^{-1} \mathrm{DM}$, respectively, $\mathrm{p}<0.001$ ). This difference became smaller, but

310 was still present at stage $5\left(46\right.$ and $39 \mu \mathrm{mol} \cdot \mathrm{g}^{-1} \mathrm{DM}$, respectively, $\left.\mathrm{p}<0.05\right)$. Vitamin levels were either

311 similar in the two groups, or higher in larvae fed rotifers/Artemia than in those fed copepods. The same

312 relationship applied to the minerals manganese, copper, zinc and selenium. Iodine was lower in larvae

313 fed rotifers than in copepods at stage $3(\mathrm{p}<0.05)$, but not at stage 5, where the groups had similar levels

314 of iodine. The fatty acid composition at stage 3 partially mirrored the fatty acid composition of the

315 feed, with a much higher EPA:ARA ratio in larvae fed copepods than in those fed rotifers (8.4 and 1.1,

316 respectively, $\mathrm{p}<0.01)$. Larvae fed rotifers had a higher DHA level than larvae fed copepods (37 and 31

$317 \%$ of total fatty acids, respectively, $\mathrm{p}<0.001)$. Although there were still statistical differences, the fatty

318 acid composition appeared similar between the larval groups at stage 5. The lipid level measured as

319 total fatty acids was similar in the two groups at stage 3, but higher in whole body of larvae fed 
320 rotifers/Artemia than in those fed zooplankton at stage $5(\mathrm{p}<0.05)$. This was followed by a lower ratio 321 of phospholipids to total lipid in cod larvae fed rotifers/Artemia in stage $5(\mathrm{p}<0.01)$.

322 The differences in nutrient composition of the live feed in Exp-2 resembled those observed in

323 Exp-1, where rotifers contained significant lower concentration of protein $(\mathrm{p}<0.001)$, taurine

$324(\mathrm{p}<0.001)$, iodine $(\mathrm{p}<0.05)$ and zinc $(\mathrm{p}<0.001)$ than copepods (Table $4 \mathrm{~b})$. The small copepod fraction is 325 dominated by nauplii, the large copepod by juvenile and adult copepods (Table 5). In this experiment, 326 the selenium level in rotifers was also lower than in copepods $(\mathrm{p}<0.001)$, but above the requirement in 327 fish of $0.3 \mathrm{mg} \mathrm{kg}^{-1} \mathrm{DM}$ (NRC 2011). There were also differences in fatty acid composition, where 328 ARA was again higher and EPA lower in rotifers $(\mathrm{p}<0.01)$. DHA was similar between the feeds. 329 Copepods had a higher ratio of phospholipids to total lipids than rotifers ( $<<0.01)$, corresponding to a 330 lower total lipid level $(\mathrm{p}<0.001)$. Vitamin A was not detected in any of the feed organisms, while 331 vitamin $\mathrm{D}$ was absent in copepods. Vitamin $\mathrm{E}(\mathrm{p}<0.01)$ and thiamine $(\mathrm{p}<0.05)$ were higher in rotifers 332 than in copepods, while vitamin $\mathrm{C}, \mathrm{Mn}$, and $\mathrm{Cu}$ levels in the two feeds were similar. Only one replicate 333 sample of the Artemia used in Exp-2 was analysed, so statistical treatment was not possible. However, 334 the Artemia seemed to have more protein and taurine than in Exp-1, but still less than the copepods.

335 The Artemia was also low in thiamine, vitamin A was not detected, while the content of other vitamins 336 was similar to that in the rotifers. The analyses in Exp-2 indicate that iodine, manganese, and zinc 337 levels were lower in Artemia than in copepods. The fatty acid composition was characterized by lower 338 DHA and EPA levels in Artemia, but higher ARA levels. Lipid level and ratio of phospholipids to total 339 lipid was similar to that in rotifers, namely with more lipid and a lower proportion of phospholipids to 340 total lipid than copepods (Table 4b). With the exception of a higher Se content and a lower iodine 341 content in large copepods, there were no significant differences in nutrient composition between small 342 and large copepods, but the variation in some of the nutrients was wide (Table $4 b$ ). 


\section{Discussion}

345 This study shows that cod larvae fed copepods grow faster than larvae fed rotifers, and thus supports

346 earlier studies (Busch et al. 2010; Busch et al. 2011; Koedijk et al. 2010). This differences in growth

347 occurred in spite of recent improvements in rotifer nutritional quality, especially with respect to lipid

348 and mineral enrichments (Hamre et al. 2013). It should be noted that during the first three weeks of

349 feeding in Exp-1, there was no difference in growth between the groups, and that the greatest

350 difference in growth rates occurred between 22 and 36 dph, i.e. when the intensive group was still

351 being fed only rotifers. Also during the Artemia feeding period, the copepod group grew slightly better,

352 but after weaning of the intensive group onto a formulated feed at $57 \mathrm{dph}$, the two groups grew at 353 similar rates.

354 We suggest at least three possible reasons for the differences in growth rate: 1) Different 355 availability of prey due to distribution or their behaviour in prey-predator interactions; 2) Different 356 energy supply per ingested feed particle due to the small size of the rotifers compared to the increasing 357 sizes of copepods given to larvae after $20 \mathrm{dph}$; 3) Differences in the nutritional values of the feeds.

358 There is a profound change in behaviour when rotifers are transferred into cold water, as they 359 typically become immobile (and thus less attractive to visual predators, such as cod larvae) and 360 gradually sink to the bottom (Fielder et al. 2000). In order to prevent sinking, our standard procedure is

361 to acclimate rotifers to the same temperature as the larval rearing tanks prior to feeding, and to aerate

362 the centre of the larval rearing tanks in order to keep the rotifers in suspension. Visual observations of

363 the rearing tanks and of ingested feed in the intestinal tracts of the larvae verified that the distribution

364 of the rotifers was constant over time and led to efficient feed intake by the larvae. High and immediate

365 feed intake of rotifers has also previously been demonstrated for naive cod larvae at onset of 
366

367

exogenous feeding in a similar startfeeding system (van der Meeren et al. 2007). It can therefore be concluded that the rotifers were highly available for the cod larvae.

With regards to the second hypothesis, the analysis shows that the energy content of copepods scaled with their size. The general pattern seems to be that when fish larvae are offered prey of different sizes, they choose the largest prey their mouth size can handle (Busch et al. 2009; Hunter 1980; Olsen et al. 2000; van der Meeren 1991), and this is also energetically the most advantageous. However, when the food is abundant, as it is under intensive farming conditions, sufficient energy may still be acquired from smaller prey consumed in larger numbers. An additional factor is that not only do larger prey items contain more energy per individual, but their surface to volume ratio also decreases, and large copepods thus contain relatively less indigestible chitinous exoskeleton. Therefore, since the rotifers have a fixed size that compares to the smaller copepod nauplii, the increase in prey size may also affect the nutritional composition if the cod larvae are given the opportunity to prey on larger copeopds. These questions were addressed in Exp-2. We found that the growth of larvae that were offered increasing size fractions of copepods or small copepod stages throughout the experiment had nearly identical growth rates. Larval dry weight was significantly, but only slightly larger at the end of the experiment for those fed the largest zooplankton. Both copepod groups grew far better than the intensive groups in both experiments.

In a similar setup that lasted only until $25 \mathrm{dph}$, Busch et al. (2011) observed a growth pattern similar to the present finding, with no significant differences between larvae fed small or large zooplankton and far better growth in both zooplankton fed groups than the cod larvae fed rotifers. This difference was only present at the end of the experiment. In their study the average length of the rotifers was $0.21 \mathrm{~mm}$, small zooplankton $0.20 \mathrm{~mm}$ and large zooplankton $0.41 \mathrm{~mm}$. This is slightly different from the zooplankton used in the present study in which the average total length of nauplii used was $0.15 \mathrm{~mm}$, while the carapace length of the copepodids was $0.38 \mathrm{~mm}$ for the $80-180 \mu \mathrm{m}$ filter 
390 fraction and about $0.5 \mathrm{~mm}$ for larger filter fractions. However, the range of prey sizes was large and

391 also overlapped in both experiments. The observed growth patterns found by Busch et al. (2011) and in

392 both of our experiments, supports the hypothesis that prey size in the range covered by our experiments

393 and under intensive larval rearing conditions with high prey density, has only minor effects on larval

394 growth. Therefore, the major cause of the differences in growth and development was most likely the

395 differences in nutritional composition between zooplankton and rotifers/Artemia. In both experiments

396 the major growth difference started to appear during the later part of the period when the larvae were

397 fed rotifers, but the difference remained during the period the larvae were fed Artemia. A similar 398 growth pattern with equal growth until approximately $20 \mathrm{dph}$ and thereafter higher growth rate in cod

399 larvae fed copepods than in those fed rotifers, was also found by Koedijk et al. (2010).

400 The third hypothesis states that there are nutritional differences in the feed that underlie the

401 differences in growth. We found major differences in the biochemical composition of rotifers and 402 zooplankton in both experiments. In Exp-1, protein, taurine, carotenoids, iodine, and zinc were lower 403 in rotifers than in copepods. The protein concentration in rotifers was similar to previous results at 404 approximately $40 \mathrm{~g} \cdot 100 \mathrm{~g}-1 \mathrm{DM}$ (Hamre et al. 2013; Srivastava et al. 2006), which represent only $2 / 3$ of 405 the concentration in copepods, and which is probably at or below the minimum requirement of cod 406 juveniles (Åsnes 2006). The nutrient composition of larvae was analysed at stage 3 when the 407 rotifer/Artemia group was still fed rotifers, and at stage 5, where both groups had been weaned onto the 408 formulated diet. Since the protein concentration in feeding animals is usually quite constant and only in 409 extreme cases affected by diet, low dietary protein will usually result in reduced growth. This was 410 confirmed by our study, since the dietary protein concentrations differed while protein concentrations 411 in the larvae were similar. Thus, the lower rate of growth in the rotifer group at stage 3 may be 412 explained by lower dietary protein. The protein concentration in Artemia used in Exp-1 was also low 413 compared to that in copepods. The reason that the growth difference occurred first after $20 \mathrm{dph}$ may be 
414 that the growth of muscle is relatively slow and characterized by recruitment of cells from 4 to $20 \mathrm{dph}$.

415 Division of cells already present in muscle, along with growth of individual muscle fibres seem to

416 speed up after $20 \mathrm{dph}$, resulting in faster muscle growth (Galloway et al. 1999) and perhaps resulting in

417 a higher protein requirement, as suggested by Hamre et al. (2014).

418 Previous studies have already found high concentrations of taurine in copepods and very low 419 concentrations in rotifers (Hamre et al. 2013; van der Meeren et al. 2008). Rock sole (Lepidopsetta 420 polyxystra) larvae fed taurine-enriched rotifers (Hawkyard et al. 2014) had a whole-body concentration 421 of taurine that was similar to the taurine concentration of copepod-fed larvae in the present study. In 422 their experiment larvae doubled their weight compared to control fish that were fed rotifers without 423 taurine enrichment during a seven-week experiment. Several other studies have also shown that taurine 424 may improve growth and development of marine fish larvae (Conceicão et al. 1997; Kim et al. 2014; 425 Pinto et al. 2010; Pinto et al. 2013a;b; Pinto et al. 2012; Takeuchi et al. 2000; Takeuchi et al. 2001). 426 Taurine is important for osmoregulation and bile salt production. Deficiencies may also result in lipid 427 accumulation, mitochondrial damage and resulting oxidative stress, neurological anomalies and heart 428 failure (Espe et al. 2008; Espe et al. 2012; Jong et al. 2012; Militante \& Lombardini 2004), suggesting 429 that taurine deficiency may cause reduced growth in cod larvae that are fed rotifers. Astaxanthin in copepods and cantaxanthin in Artemia may act as antioxidants (Stahl \& Sies

431 1999) or as pro-vitamin A compounds (Rønnestad et al. 1998; Moren et al. 2002). In Exp-1, the

432 vitamin A requirement of intensively reared cod larvae (Moren et al. 2004) was most probably covered 433 by retinol in the rotifers, since the larval vitamin A level was similar to that in the copepod-fed group.

434 Carotenoids were not analysed in the larvae of the present study, but visual examination showed that 435 copepod-fed larvae displayed more colour than rotifer-fed larvae, as was also observed by Øie et al. 436 (unpublished) and Busch et al. (2011). However, based on the well-known antioxidant effects of 
carotenoids (Stahl \& Sies 1999), it is unlikely that these differences would result in the large

divergences of larval growth observed by us.

The concentration of iodine was considerably lower in the rotifers than in the copepods. However, the optimal level of iodine in rotifers has been estimated at $3.5 \mathrm{mg} \cdot \mathrm{kg}^{-1} \mathrm{DM}$ (Penglase et al. 2013), which is within the range of variation of the levels in the rotifers analysed in the present experiment. It is therefore unlikely that iodine deficiency caused the reduced growth in rotifer-fed larvae.

Zinc is a necessary co-factor in the catalytic activity of more than 300 proteins involved in growth, reproduction, development and vision (Bury et al. 2003). In our study, the level of zinc in copepods was more than ten times as high as in rotifers. Despite this, the larval concentrations at stage

4473 were similar for the two feeding regimes at approximately $120 \mathrm{mg} \cdot \mathrm{kg}^{-1}$, in line with the recognised tight regulation of zinc levels in fish, both at cellular and organism level (Bury et al. 2003). Penglase et al. (2013) fed cod larvae rotifers enriched with zinc to $87 \mathrm{mg} \cdot \mathrm{kg}^{-1} \mathrm{vs.} 47 \mathrm{mg} \cdot \mathrm{kg}^{-1}$ in the control rotifers, without producing any detectable differences in growth. Combined with the present results and the 451 zinc requirements of fish (15-37 $\left.\mathrm{mg} \cdot \mathrm{kg}^{-1}, \mathrm{NRC} 2011\right)$, this indicates that rotifers in the present experiment had sufficient levels of zinc to promote growth in the larvae.

The fatty acid and lipid composition of rotifers and zooplankton displayed certain differences in 454 both experiments. In Exp-1, ARA and DHA made up a lower, and EPA a higher, fraction of total fatty acids in rotifers than in copepods, and the proportion of phospholipids (PL) to total lipids was slightly 456 lower in the rotifers. However, the differences in PL and fatty acid composition were probably not sufficient to explain the large difference in growth. be lower in rotifers than in copepods (Hamre et al. 2008a), were at similar levels in the present experiment. All the other nutrients measured were present at higher or similar levels in the rotifers and 
461 copepods, and according to current knowledge, within the safe window of larval requirements. Apart

462 from thiamine and the macrominerals, B vitamins were not analysed, since they have already been

463 shown to be sufficient in rotifers, based on comparisons with copepods (Hamre et al. 2008a).

There were some important differences in the nutrient composition of live prey between Exp-1

466 the requirement given for fish (NRC 2011). Furthermore, vitamin A was below the detection limit of

467 the analytical method in all prey organisms in Exp-2. Artemia and copepods contain sufficient amounts

468 of carotenoids to cover the vitamin A requirement of the larvae (Moren et al. 2002), but in larvae fed

469 rotifers in Exp-2, vitamin A may have been deficient. The lipid level in rotifers was higher than in

470 copepods in Exp-2, and the proportion of PL to total lipid was therefore higher in the copepods.

471 Finally, the concentration of protein in Artemia was higher in Exp-2 than Exp-1. The rearing

472 temperature was also different between the experiments. Given all these differences in nutritional and

473 physical conditions, the growth patterns were strikingly comparable between the experiments in this

474 study, and to that observed by Busch et al. (2011). The growth in larvae fed rotifers may have been

475 further reduced in Exp-2 due to a low vitamin A level, but the similarity in nutrient composition

between small and large copepods, along with similar growth rates in the larvae fed on these, strongly suggests that prey size was of minor importance for the difference in growth observed in Exp-1.

In conclusion, differences in nutritional composition of prey are the most plausible explanation

479 for the major divergences in growth and development of cod larvae fed natural zooplankton versus

480 larvae fed enriched rotifers and Artemia. Low levels of protein and/or taurine in rotifers and Artemia

481 are most likely the cause of poor growth in larvae fed rotifers. Since taurine is a water-soluble

482 compound, large amounts are needed for rotifer enrichment, unless it is incorporated directly into

483 particles that can be filtered out of the water (Hawkyard et al. 2014; Nordgreen et al. 2007). If poor

484 growth is related to the low protein concentration in the rotifers, it might be more difficult to correct, 
485 since rotifers cannot easily be enriched with protein due to their own metabolism (Hamre et al. 2013).

486 Possible suboptimal levels of zinc and carotenoids, ratio of PL/TL, and composition of fatty acids may

487 also have contributed to slow growth in the cod larvae fed rotifers. However, these nutrients can be

488 manipulated to a certain extent in rotifers (Hamre et al. 2013; Nordgreen et al. 2013; Olsen et al. 2014).

489 The larval requirements for all nutrients in cod cannot easily be met by means of traditional protocols

490 for enriching rotifers and Artemia. This require development of new protocols and adoption of new

491 approaches to live feed enrichment during cultivation of early life stagesin cod and other marine fish.

\section{Acknowledgements}

495 We thank the following technical staff at IMR Austevoll for their excellent assistance with the 496 experiments; Stig Ove Utskot, Lillian Eggøy, Annhild Engevik, Margareth Møgster, Velimir Nola, 497 Albert Rams, Michael Rejmer, Signe Lise Storebø and the technical staff at NIFES, in particular 498 Kjersti Ask, the responsible technician for the nutritional analyses. The work was funded by the 499 Ministry of Fisheries and Coastal Affairs and the Research Council of Norway (CODE knowledge 500 platform project; Grant no. 199482/S40). 


\section{References}

503 Bury NR, Walker PA, and Glover CN. 2003. Nutritive metal uptake in teleost fish. Journal of Experimental Biology 206:11-23.

505 Busch KET, Falk-Petersen I-B, Peruzzi S, Rist NA, and Hamre K. 2010. Natural zooplankton as larval feed in intensive rearing systems for juvenile production of Atlantic cod (Gadus morhua L.).

508

509

510

511

512

513

514

515

516

517 Aquaculture Research 41:1727-1740.

Busch KET, Folkvord A, Otterå H, Hutchinson WF, and Svåsand T. 2009. Effects of female spawning experience and larval size on feeding and growth of cod larvae Gadus morhua L. reared in mesocosms. Marine Biology Research 5:286-296.

Busch KET, Peruzzi S, Tonning F, and Falk-Petersen IB. 2011. Effect of prey type and size on the growth, survival and pigmentation of cod (Gadus morhua L.) larvae. Aquaculture Nutrition 17:e595-e603.

Cahu CL, Zambonino Infante JL, Barbosa V, 2003. Effect of dietary phospholipid level and phospholipid: neutral lipid value on the development of sea bass (Dicentrarchus labrax) larvae fed a compound diet. British Journal of Nutrition, 90:21-28.

Conceicão L, van der Meeren T, Verreth JAJ, Evjen MS, Houlihan DF, and Fyhn HJ. 1997. Amino acid metabolism and protein turnover in larval turbot (Scophthalmus maximus) fed natural zooplankton or Artemia. Marine Biology 129:255-265.

Espe M, Hevrøy EM, Liaset B, Lemme A, and El-Mowafi A. 2008. Methionine intake affects hepatic sulphur metabolism in Atlantic salmon, Salmo salar. Aquaculture 274:132-141.

Espe M, Ruohonen K, and El-Mowafi A. 2012. Effect of taurine supplementation on the metabolism and body lipid-to-protein ratio in juvenile Atlantic salmon (Salmo salar). Aquaculture Research 43:349-360. 
525 Evjemo JO, Reitan KI, and Olsen Y. 2003. Copepods as live food organisms in the larval rearing of halibut larvae (Hippoglossus hippoglossus L.), with special emphasis on the nutritional value. Aquaculture 277:191-210.

528 Fielder DS, Purser GJ, and Battaglene SC. 2000. Effect of rapid changes in temperature and salinity on availability of the rotifers Brachionus rotundiformis and Brachionus plicatilis. Aquaculture 189:85-99.

531 Fjelldal PG, van der Meeren T, Jørstad KE, and Hansen TJ. 2009. A radiological study on vertebral deformities in cultured and wild Atlantic cod (Gadus morhua, L.). Aquaculture 289:6-12.

533 Galloway TF, Kjørsvik E, Kryvi H, 1999. Muscle growth and development in Atlantic cod larvae (Gadus morhua L.) related to different somatic growth rates. Journal of Experimental Biology 202:2111-2120.

Hamre K, Srivastava A, Rønnestad I, Mangor-Jensen A, and Stoss J. 2008a. Several micronutrients in the rotifer Brachionus sp. may not fulfil the nutritional requirements of marine fish larvae. Aquaculture Nutrition 14:51-60.

Hamre K, Mollan TA, Sæle Ø, and Erstad B. 2008b. Rotifers enriched with iodine and selenium increase survival in Atlantic cod (Gadus morhua) larvae. Aquaculture 284:190-195.

Hamre K, Yúfera M, Rønnestad I, Boglione C, Conceição LEC, and Izquierdo M. 2013. Fish larval nutrition and feed formulation: knowledge gaps and bottlenecks for advances in larval rearing. Reviews in Aquaculture 5:S26-S58.

Hamre K, Penglase SJ, Rasinger JD, Skjærven KH, and Olsvik PA. 2014. Ontogeny of redox regulation in Atlantic cod (Gadus morhua) larvae. Free Radical Biology and Medicine 73:337348.Harboe T, Huse I, and Øie G. 1994. Effects of egg disinfection on yolk sac and first feeding stages of halibut (Hippoglossus hippoglossus L.) larvae. Aquaculture 119:157-165. 
548 Harboe T, Huse I, and Øie G. 1994. Effects of egg disinfection on yolk sac and first feeding stages of halibut (Hippoglossus hippoglossus L.) larvae. Aquaculture 119:157-165.

550 Hawkyard M, Laurel B, and Langdon C. 2014. Rotifers enriched with taurine by microparticulate and 551 dissolved enrichment methods influence the growth and metamorphic development of northern rock sole (Lepidopsetta polyxystra) larvae. Aquaculture 424-425:151-157.

Hunt von Herbing I, Boutilier RG, Miyake T, and Hall BK. 1996. Effects of temperature on morphological landmarks critical to growth and survival in larval Atlantic cod (Gadus morhua). Marine Biology. p 593-606.

Hunter JR. 1980. The feeding behaviour and ecology of marine fish larvae. In Fish behaviour and its use in the capture and culture of fishes. Eds. Bardach, JE. JJ. Magnuson, RC. May, JM. Reinhart. ICLARM. Conference Proceedings, Manila, Philippines. p 287-330.

Imsland AK, Foss A, Koedijk R, Folkvord A, Stefansson SO, and Jonassen TM. 2006. Short- and longterm differences in growth, feed conversion efficiency and deformities in juvenile Atlantic cod (Gadus morhua) startfed on rotifers or zooplankton. Aquaculture Research 37:1015-1027.

Jong C, Azuma J, and Schaffer S. 2012. Mechanism underlying the antioxidant activity of taurine: prevention of mitochondrial oxidant production. Amino Acids 42:2223-2232.

Jordal AEO, Lie Ø, Torstensen BE, 2007. Complete replacement of dietary fish oil with a vegetable oil blend affects liver lipid and plasma lipoprotein levels in Atlantic salmon (Salmo salar L.). Aquaculture Nutrition 13:114-130. development and long-term consequences for growth. Journal of Fish Biology 77:1-19. 
570 Kim Y-S, Sasaki T, Awa M, Inomata M, Honryo T, Agawa Y, Ando M, and Sawada Y. 2014. Effect of dietary taurine enhancement on growth and development in red sea bream Pagrus major larvae. Aquaculture Research, doi:10.1111/are.12573

573 Kuhlman D., Quantz G. and Witt U. 1981. Rearing of turbot larvae (Scophthalmus maximus L.) on cultured food organisms and postmetamorphosis growth on natural and artificial food. Aquaculture 23:183-196.

Last JM. 1978. The food of three species of gadoid larvae in the Eastern English Channel and southern

578 North Sea. Marine Biology 48: 377-386.

Liu G, and Xu D. 2009. Effects of calanoid copepod Schmackeria poplesia as a live food on the growth, survival and fatty acid composition of larvae and juveniles of Japanese flounder, Paralichthys olivaceus. Journal of Ocean University China (Oceanic and Coastal Sea Research) $8: 359-365$.

Militante JD, and Lombardini JB. 2004. Dietary taurine supplementation: hypolipidemic and antiatherogenic effects. Nutrition Research 24:787-801.

Moren M, Næss T, and Hamre K. 2002. Conversion of $\beta$-carotene, canthaxanthin and astaxanthin to vitamin A in Atlantic halibut (Hippoglossus hippoglossus L.) juveniles. Fish Physiology and Biochemistry 27:71-80.

Moren M, Opstad I, and Hamre K. 2004. A comparison of retinol, retinal and retinyl ester concentrations in larvae of Atlantic halibut (Hippoglossus hippoglossus L.) fed Artemia or zooplankton. Aquaculture Nutrition 10:253-259.

Naas KE, Næss T, and Harboe T. 1992. Enhanced first feeding of halibut larvae (Hippoglossus hippoglossus L.) in green water. Aquaculture 105:143-156.

Naas KE, van der Meeren T, and Aksnes DL. 1991. Plankton succesion and responses to manipulations in a marine basin for larval fish rearing. Marine Ecology Progress Series 74:161-173. 
594 Nordgreen A, Hamre K, and Langdon C. 2007. Development of lipid microbeads for delivery of lipid 595 and water-soluble materials to Artemia. Aquaculture 273:614-623.

596 Nordgreen A, Penglase S, and Hamre K. 2013. Increasing the levels of the essential trace elements Se, $597 \mathrm{Zn}, \mathrm{Cu}$ and $\mathrm{Mn}$ in rotifers (Brachionus plicatilis) used as live feed. Aquaculture 380-383:120$598 \quad 129$.

599 NRC. 2011. Nutrient Requirements of Fish and Shrimp. Animal Nutrition series. National Research 600 Council, USA. ISBN: 978-0-309-16338-5

601 Olsen AI, Attramadal Y, Reitan KI, and Olsen Y. 2000. Food selection and digestion characteristics of 602 603 Atlantic halibut Hippoglossus hippoglossus larvae fed cultivated prey organisms. Aquaculture $181: 293-310$.

604

605

606 performance. Aquaculture 428:203-214.

607

608

609

610

611

612

Olsen Y, Evjemo JO, Kjørsvik E, Larsen H, Li K, Overrein I, and Rainuzzo JR. 2014. DHA content in dietary phospholipids affects DHA content in phospholipids of cod larvae and larval

Penglase S, Harboe T, Sæle Ø, Helland S, Nordgreen A, and Hamre K. 2013. Iodine nutrition and toxicity in Atlantic cod (Gadus morhua) larvae. PeerJ 1:e20.

Penglase S, Nordgreen A, van der Meeren T, Olsvik PA, Sæle Ø, Sweetman JW, Baeverfjord G, Helland S, and Hamre K. 2010. Increasing the level of selenium in rotifers (Brachionus plicatilis 'Cayman') enhances the mRNA expression and activity of glutathione peroxidase in

613 Pinto W, Figueira L, Ribeiro L, Yúfera M, Dinis MT, and Aragão C. 2010. Dietary taurine 614 supplementation enhances metamorphosis and growth potential of Solea senegalensis larvae. $615 \quad$ Aquaculture 309:159-164. 
616 Pinto W, Figueira L, Santos A, Barr Y, Helland S, Dinis MT, and Aragão C. 2013a. Is dietary taurine supplementation beneficial for gilthead seabream (Sparus aurata) larvae? Aquaculture 384$387: 1-5$

Pinto W, Rønnestad I, Jordal A-E, Gomes A, Dinis M, and Aragão C. 2012. Cloning, tissue and ontogenetic expression of the taurine transporter in the flatfish Senegalese sole (Solea senegalensis). Amino Acids 42:1317-1327.

622

623

624

625

626

627

628

629

630

631

632

633

634

635

636

637

638

639 aquaculture industry. In A El Idrissi and WJ L'Amoreaux (eds.). Advances in Experimental Medicine and Biology. 776, 329-334.

Ricker WE. 1979. Growth rates and models. Fish Physiology. 8:677-743.

Rønnestad I, Hemre GI, Finn RN, Lie Ø. 1998. Alternate sources and dynamics of vitamin A and its incorporation into the eyes during the early endotrophic and exotrophic larval stages of Atlantic halibut (Hippoglossus hippoglossus L.). Comparative Biochemistry and Physiology AMolecular \& Integrative Physiology 119:787-793.

Srivastava A, Hamre K, Stoss J, Chakrabarti R, and Tonheim SK. 2006. Protein content and amino acid composition of the live feed rotifer (Brachionus plicatilis): With emphasis on the watersoluble fraction. Aquaculture 254:534-543.

Srivastava A, Hamre K, Stoss J, and Nordgreen A. 2012. A study on enrichment of the rotifer Brachionus "Cayman” with iodine from different sources. Aquaculture 334-337:82-88.

Srivastava A, Stoss J, and Hamre K. 2011. A study on enrichment of the rotifer Brachionus "Cayman" with iodine and selected vitamins. Aquaculture 319:430-438.

Stahl W, and Sies H. 1999. Carotenoids: occurrence, biochemical activities, and bioavailability. In: Packer L, Hiramatsu M, and Yoshikaw T, eds. Antioxidant food supplements in human health. San Diego, CA: Academic Press, 183-202. 
640 Stepien WP. 1976. Feeding of laboratory-reared larvae of the sea-bream Archosargus rhomboidalis 641 (Sparidae). Marine Biology 38:1-16.

642 Takeuchi K, Toyohara H, Kinoshita M, and Sakaguchi M. 2000. Ubiquitous increase in taurine 643 transporter mRNA in tissues of tilapia (Oreochromis mossambicus) during high-salinity

645 Takeuchi T, Park GS, Seikai T, and Yokoyama M. 2001. Taurine content in Japanese flounder 646 Paralichthys olivaceus T. \& S. and red sea bream Pagrus major T. \& S. during the period of

648 van der Meeren T. 1991. Selective feeding and prediction of food consumption in turbot larvae 649 650 (Scophthalmus maximus L.) reared on the rotifer Brachionus plicatilis and natural zooplankton.

651 van der Meeren T, Brunvold L, Sandaa R-A, Bergh Ø, Castberg T, Thyrhaug R, and Mangor-Jensen A. 652 2011. Water quality and microbial community structure in juvenile Atlantic cod (Gadus 654 van der Meeren T, Harboe T, Holm JC, and Solbakken R. 1998. A new cleaning system for rearing 655 tanks in larval fish culture. ICES CM L13. 12pp.

656 van der Meeren T, Karlsen Ø, Liebig PL, and Mangor-Jensen A. 2014. Copepod production in a 657 658 659 van der Meeren T, and Lønøy T. 1998. Use of mesocosms in larval rearing of saithe [Pollachius virens 660 (L.)], goldsinny [Ctenolabrus rupestris (L.)], and corkwing [Crenilabrus melops (L.)]. 661 Aquacultural Engineering. 17:253-260. 
662 van der Meeren T, Mangor-Jensen A, and Pickova J. 2007. The effect of green water and light intensity 663 on survival, growth and lipid composition in Atlantic cod (Gadus morhua) during intensive larval rearing. Aquaculture 265:206-217.

665 van der Meeren T, Olsen RE, Hamre K, and Fyhn HJ. 2008. Biochemical composition of copepods for 666 evaluation of feed quality in production of juvenile marine fish. Aquaculture 274:375-397.

667 Wiborg KF. 1948. Investigations on cod larvae in the coastal waters of northern Norway. 668 Fiskeridirektoratets skrifter, Serie Havundersøkelser 9:27pp.

Yacoob SY, Browman HI, and Jensen PA. 2004. Electroencephalogram recordings from the olfactory bulb of juvenile (0 year) Atlantic cod in response to amino acids. Journal of Fish Biology 65:1657-1664.

Øie G, Galloway TF, Sørøy M, Hansen MH, Norheim IA, Halseth CK, Almli M, Berg M, Gagnat MR, Wold PA, Attramadal Y, Hagemann A, Evjemo JO, and Kjørsvik E. Submitted. Cultivated copeods (Acartia tonsa) in first feeding of Atlantic cod (Gadus morhua) and ballan wrasse (Labrus bergylta) larvae.

676 Åsnes ER. 2006. Optimal makronæringsstoffsammensetning i fôr til torskeyngel (Gadus morhua) og effekt av pepsinhydrolysert protein i fôr på vekst og overlevelse (in Norwegian) Master's thesis, University of Bergen, Norway, $77 \mathrm{pp}$.

679 
1

Physical conditions of experiments

Figure 1. Water temperature, relative water exchange rate given as tank volume $\cdot$ day ${ }^{-1}$, and oxygen saturation during the experimental period (4-90 dph) for the copepod and the rotifer/ Artemia groups in both experiments (Exp-1 and Exp-2).

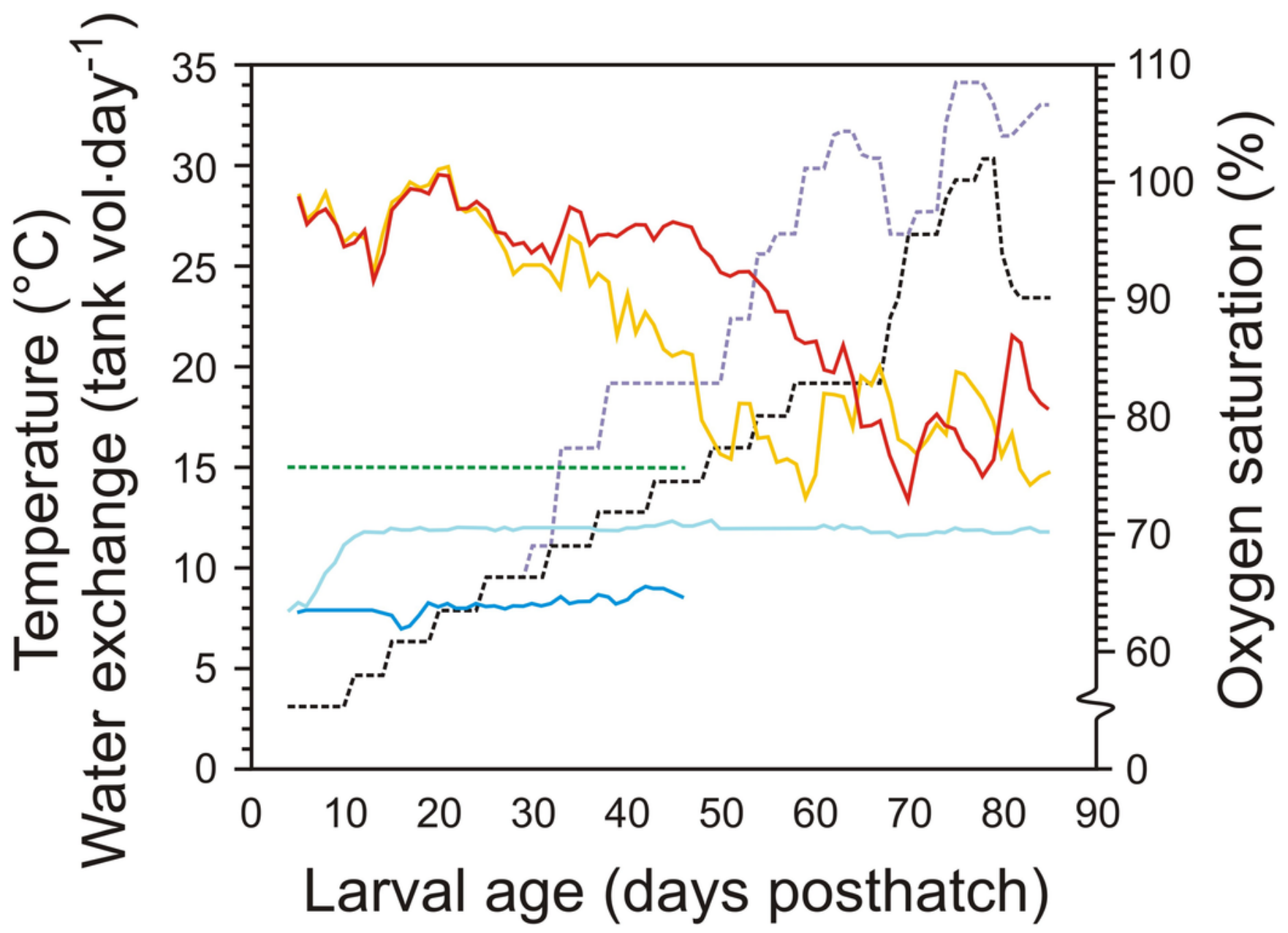

---- Exchange Exp-1, Rotifers

---- Exchange Exp-1, Copepods

- Oxygen Exp-1, Rotifers Oxygen Exp-1, Copepods
Exchange Exp-2 Temperature Exp-1 Temperature Exp-2 
2

Feeding regime in Exp-1

Figure 2. Feeding regimes, sampling (black triangles), and use of "green water" (where an algal paste is added to the water) in Exp-1; a) larvae fed rotifers and Artemia , b) copepod feeding regime. Copepod size fractions are given between the vertical dotted lines. Particle diameter is given for formulated feed: AgloNorse (AN) and Gemma Diamond (GD).

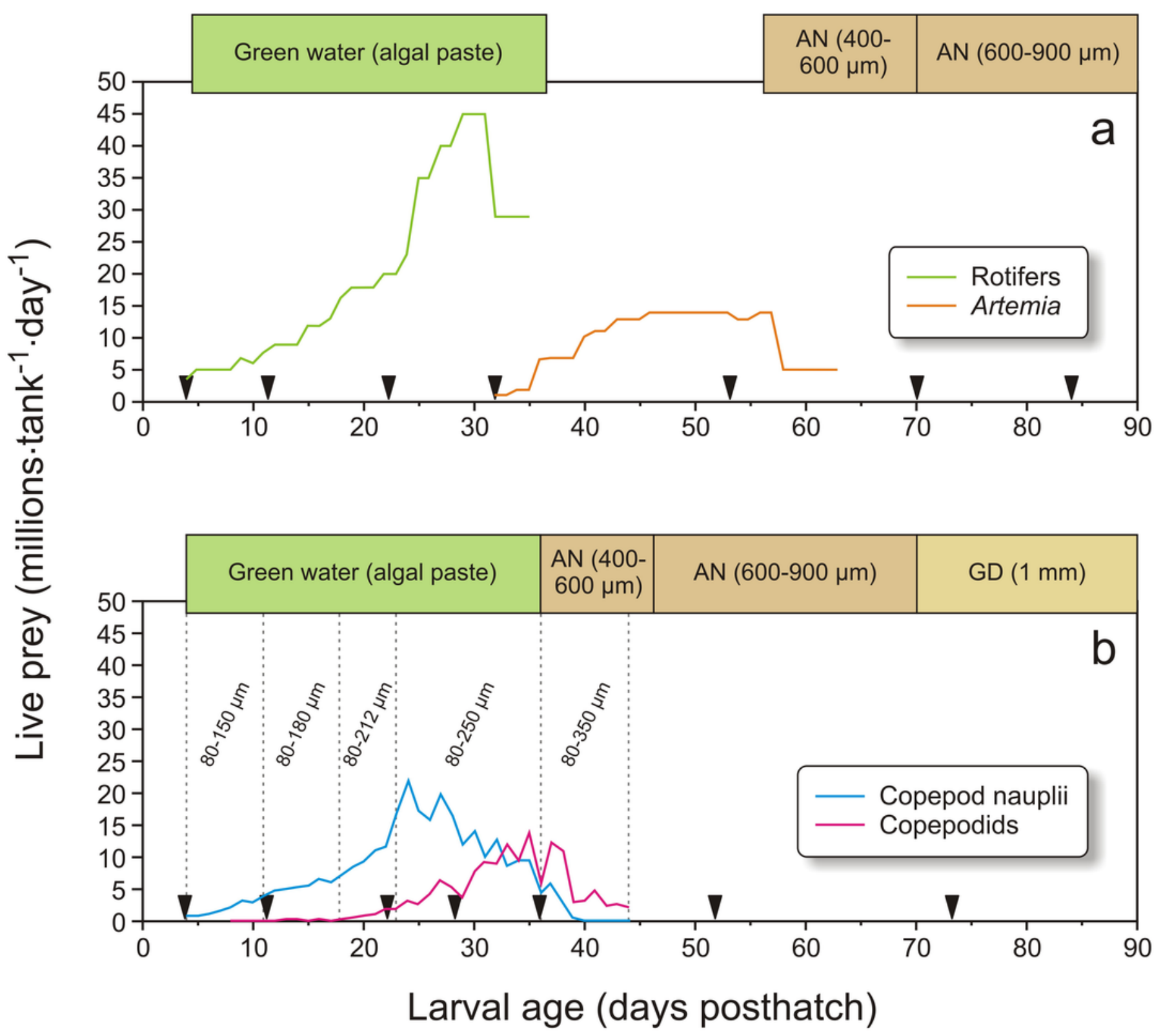




\section{3}

Feeding regime in Exp-2

Figure 3. Feeding regimes, sampling (black triangles), and use of green water in Exp-2; a) feeding regime with rotifers and Artemia, b) copepod feeding regime with increasing prey size, and c) copepod feeding regime with small prey size. Copepod size fractions are given between the vertical dotted lines.

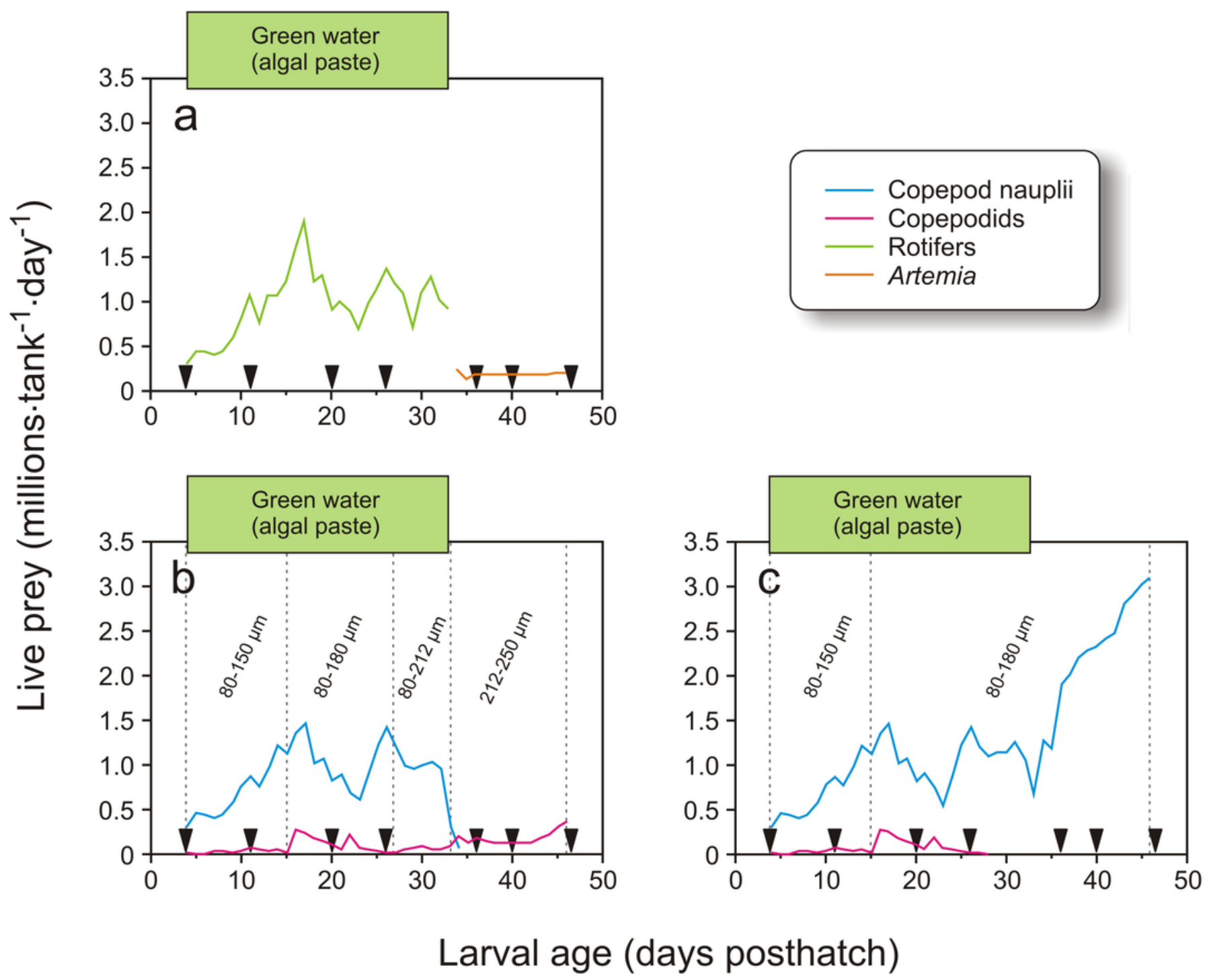




\section{4}

Copepod size fractions

Figure 4. Mean prosome (copepodids) or total length (nauplii), quartiles (box) and range (lines) of nauplii (open) and copepodids (grey) in the different filter fractions used as feed in the experiments. No nauplii were present in the $180-250 \mu \mathrm{m}$ or $212-250 \mu \mathrm{m}$ fractions.

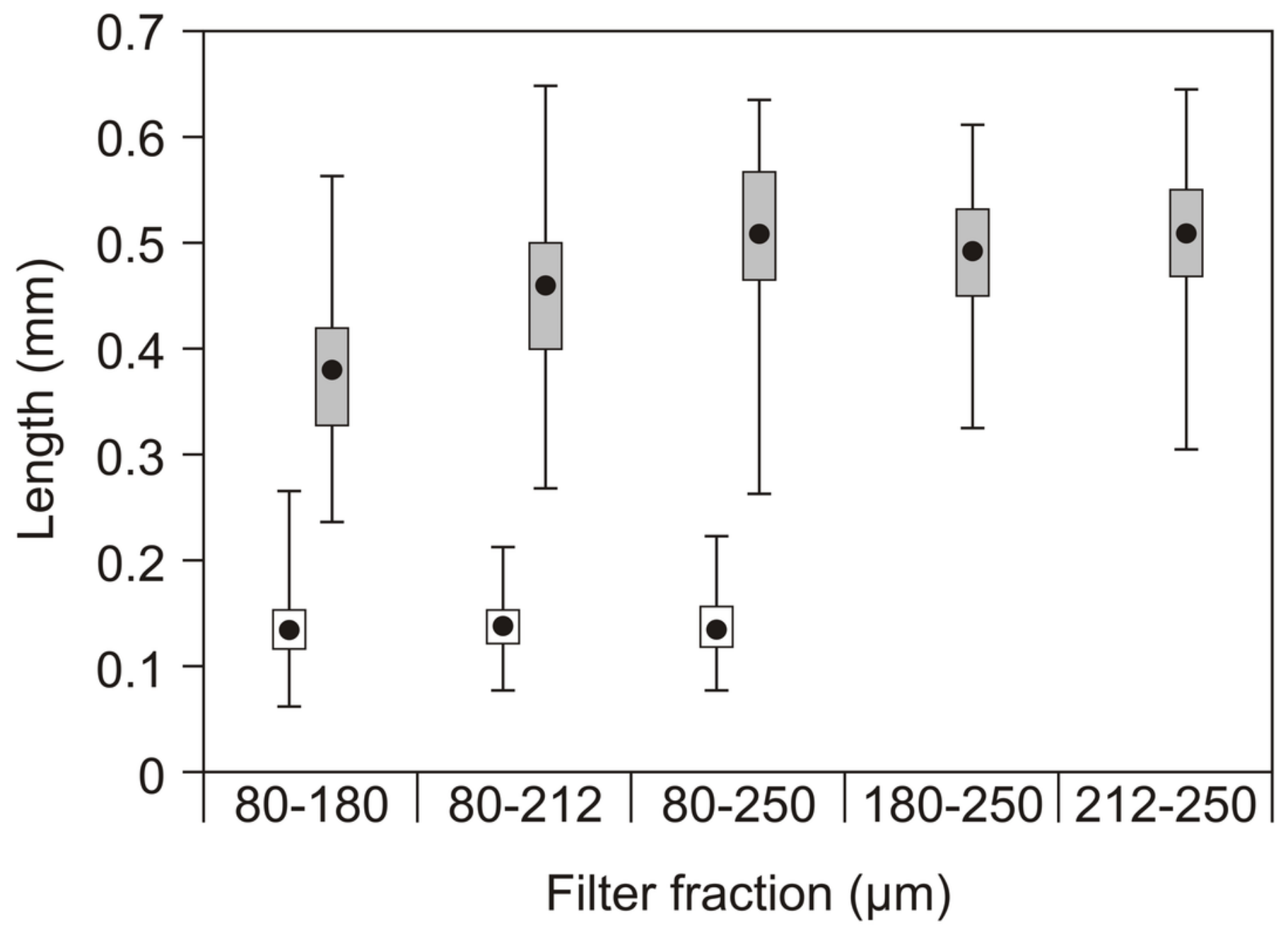




\section{5}

Growth in length and dry weight in both experiments

Figure 5: Growth in length $(\mathrm{mm})$ and dry weight $(\mathrm{mg})$ in Exp-1 ( $\mathrm{a}$ and $\mathrm{c}$ ) and Exp-2 (b and d) of cod larvae fed either rotifers and Artemia or copepods. In Exp-1, larvae were fed copepods of increasing size. Stages (St.0-5 and Juveniles, see text for explanation) are indicated. In exp-2, one group was fed copepod nauplii and another group copepods of increasing size. Note logarithmic scale in $\mathrm{c}$ and $\mathrm{d}$. 

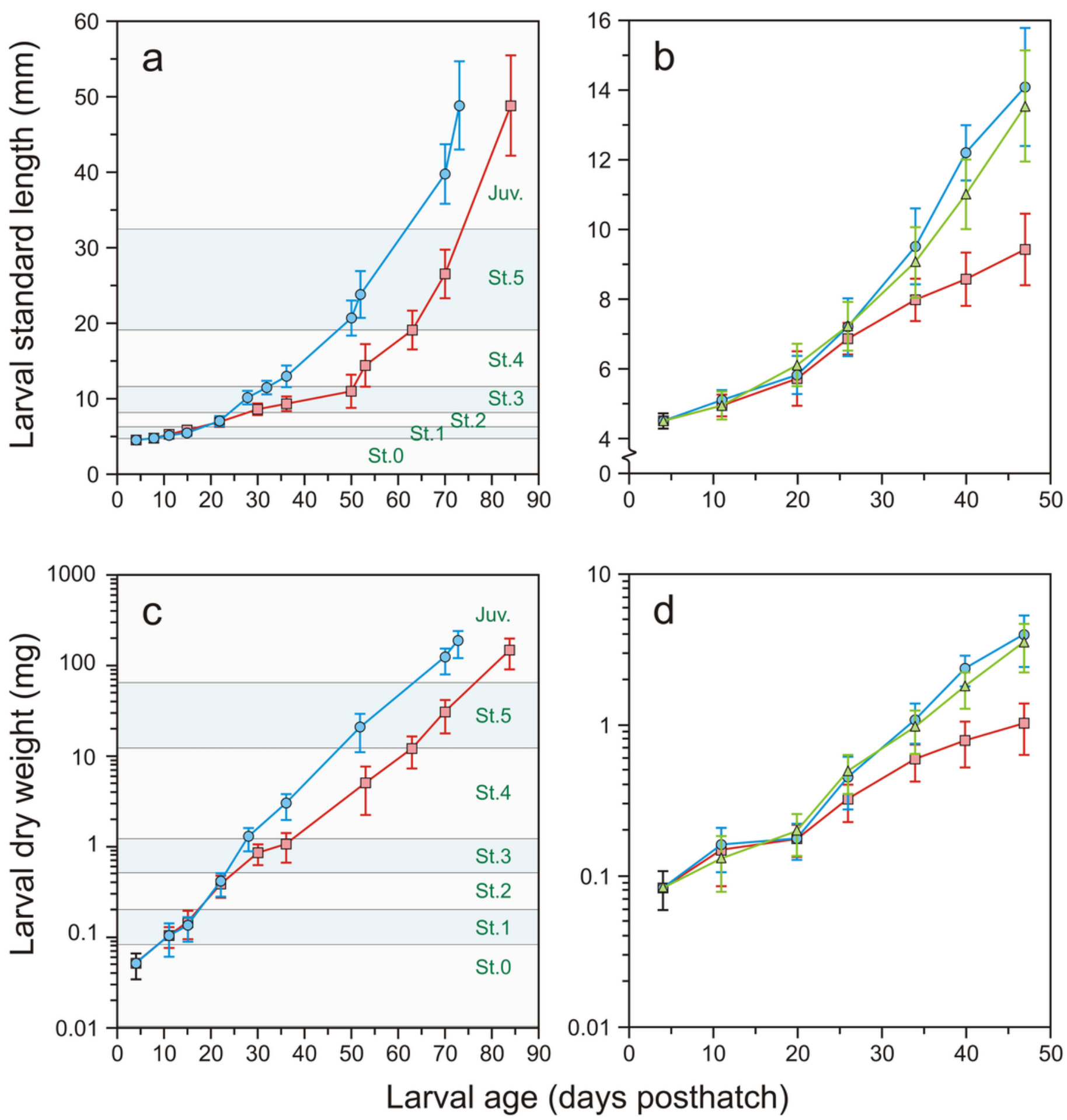

$-\circ$ Copepod nauplii and copepodids

$\triangle$ Copepod nauplii

$\rightarrow \square$ Rotifers and Artemia 


\section{Table $\mathbf{1}_{\text {(on next page) }}$}

Overview of the sampling in Exp-1

Table 1. Analytical methods for the different nutrientsTable 2: Overview of larval stages at sampling in Exp-1, corresponding larval age and standard length (SL, mean $\pm S D$ ) and approximate number of larvae sampled per tank (No). Superscript letters indicate significant differences between treatments in SL (t-test, $p<0.05$ ). Larvae were fed either copepods or rotifers in stages 0-3 and Artemia in stages 3-4 (Rotifers). Both groups were weaned after the sampling at stage 4. Stages were described by Sæle et al. (in preparation) and correlated with those given by (Hunt von Herbing et al. 1996) 


\begin{tabular}{|c|c|c|c|c|c|c|}
\hline \multirow[t]{2}{*}{ Stage } & \multicolumn{2}{|c|}{ Age (dph) } & \multicolumn{2}{|l|}{ SL (mm) } & \multicolumn{2}{|l|}{ No } \\
\hline & Rotifers & Copepods & Rotifers & Copepods & Rotifers & Copepods \\
\hline$\overline{0}$ & 4 & 4 & $4.5 \pm 0.2$ & $4.5 \pm 0.2$ & 3350 & 5300 \\
\hline 1 & 11 & 11 & $5.2 \pm 0.4$ & $5.1 \pm 0.3$ & 3850 & 3400 \\
\hline 2 & 22 & 22 & $6.9 \pm 0.6$ & $7.0 \pm 0.7$ & 2180 & 1800 \\
\hline 3 & 31 & 29 & $8.5 \pm 0.7$ & $10.1 \pm 0.9$ & 1550 & 2800 \\
\hline 4 & 54 & 37 & $14.8 \pm 2.6$ & $12.9 \pm 1.4$ & 1435 & 1300 \\
\hline 5 & 71 & 53 & $26.5 \pm 3.2^{\mathrm{a}}$ & $23.7 \pm 3.1^{b}$ & 1360 & 1300 \\
\hline Juvenile & 85 & 74 & $48.8 \pm 6.6$ & $48.9 \pm 5.8$ & 1350 & 1200 \\
\hline
\end{tabular}




\section{Table 2 (on next page)}

Analytical methods employed

Table 2. Analytical methods for the different nutrients 


\begin{tabular}{lll}
\hline Analyte & Principle & Reference \\
\hline Dry matter & Gravimetric after freeze drying & Hamre \& Mangor-Jensen 2006 \\
Protein & N x 6.25 Leco N Analyzer & Hamre \& Mangor-Jensen 2006 \\
Taurine & Total amino acids & Espe et al. 2006 \\
Fatty acids & Transmethylation extraction and GC/FID & Lie \& Lambertsen 1991 \\
& & \\
Lipid classes & HPTLC & Jordal et al. 2007 \\
Vitamin C & HPLC & Mæland \& Waagbø 1998 \\
Vitamin A & HPLC & Moren et al. 2002 \\
Vitamin D & HPLC & CEN 1999 \\
Vitamin E & HPLC & Hamre et al. 2010 \\
Sum vitamin K & HPLC & CEN 2003 \\
Carotenoids & HPLC & Ørnsud et al. 2004 \\
Microminerals & ICP-MS & Julshamn et al. 2004 \\
Iodine & ICPMS & Julshamn et al. 2001 \\
\hline
\end{tabular}




\section{Table 3(on next page)}

\section{Larval growth rates}

Table 3. Daily length increment (DLI, mm*day ${ }^{-1}$ ) and specific growth rate (SGR, weight*\%day ${ }^{-1}$ ) of cod larvae fed rotifers and Artemia (Rotifers) or copepods duringthe start-feeding period. Superscripts indicate significant differences in tank means during the periods (Exp-1 t-test; Exp-2 one way ANOVA and Tukey HSD, $p<0.05$ ).a) Exp-1, $n=3$, calculations based on stages; b) Exp-2, $n=4$, calculations based on age. Data are given as mean $\pm \mathrm{SD}$. 


\begin{tabular}{llllll}
\hline a) Stages & DLI & & & SGR & \\
\cline { 6 - 7 } \cline { 5 - 6 } (age as dph, rot/cop) & Rotifers & Copepod & & Rotifers & Copepod \\
\hline $0-2(4-22 / 4-22)$ & $0.13 \pm 0.03$ & $0.14 \pm 0.02$ & & $11.9 \pm 1.0$ & $11.9 \pm 1.6$ \\
2-4 $(22-36 / 22-53)$ & $0.25 \pm 0.05^{\mathrm{a}}$ & $0.42 \pm 0.06^{\mathrm{b}}$ & & $8.6 \pm 0.4^{\mathrm{a}}$ & $15.5 \pm 2.5^{\mathrm{b}}$ \\
4-5 (36-52/53-70) & $0.73 \pm 0.04$ & $0.67 \pm 0.01$ & & $11.6 \pm 0.8$ & $12.9 \pm 0.7$ \\
5-Juvenile $(52-73 / 70-84)$ & $1.58 \pm 0.29$ & $1.25 \pm 0.05$ & & $12.0 \pm 1.9$ & $11.4 \pm 0.4$ \\
\hline
\end{tabular}

\begin{tabular}{|c|c|c|c|c|c|c|}
\hline \multirow{2}{*}{$\begin{array}{l}\text { b) Period } \\
\text { (dph) }\end{array}$} & \multicolumn{3}{|l|}{ DLI } & \multicolumn{3}{|l|}{ SGR } \\
\hline & Rotifers & Small cop. & Large cop. & Rotifers & Small cop. & Large cop. \\
\hline $4-20$ & $0.08 \pm 0.02^{\mathrm{a}}$ & $0.10 \pm 0.01^{\mathrm{a}}$ & $0.08 \pm 0.01^{\mathrm{a}}$ & $4.74 \pm 0.69^{\mathrm{a}}$ & $5.46 \pm 0.57^{\mathrm{a}}$ & $4.75 \pm 0.43^{\mathrm{a}}$ \\
\hline $20-34$ & $0.16 \pm 0.05^{\mathrm{a}}$ & $0.21 \pm 0.02^{\mathrm{ab}}$ & $0.26 \pm 0.02^{b}$ & $8.93 \pm 2.15^{\mathrm{a}}$ & $12.0 \pm 0.6^{\mathrm{b}}$ & $13.8 \pm 1.0^{\mathrm{b}}$ \\
\hline $34-47$ & $0.11 \pm 0.02^{\mathrm{a}}$ & $0.35 \pm 0.04^{b}$ & $0.35 \pm 0.04^{b}$ & $4.44 \pm 1.08^{\mathrm{a}}$ & $10.4 \pm 1.1^{\mathrm{b}}$ & $10.4 \pm 1.8^{\mathrm{b}}$ \\
\hline
\end{tabular}




\section{Table 4(on next page)}

Nutrient levels in live food

Table 4. Leves of selected nutrient in the live feed used for cod larvae in A) Exp-1 (mean $\pm S D, n=2$ for Artemia, $n=3$ for rotifers and copepods) and B) Exp-2 ( $n=1$ for Artemia , $n=2$ for rotifers, $n=3$ for small and large copepods; n.d., not detected). Superscripts indicate significant differences (ANOVA and Tukey's post hoc test, $p<0.05$ ). 


\begin{tabular}{|c|c|c|c|}
\hline A & Rotifers & Artemia & Zooplankton \\
\hline Dry matter (DM, g/100 g) & $12 \pm 1^{\mathrm{a}}$ & $19 \pm 2^{b}$ & $20 \pm 2^{b}$ \\
\hline Protein $(g / 100$ g DM) & $37 \pm 4^{\mathrm{a}}$ & $39 \pm 0^{\mathrm{a}}$ & $60 \pm 2^{b}$ \\
\hline Taurine ( $\mu \mathrm{mol} / \mathrm{g} \mathrm{DM})$ & $0.8 \pm 0.3^{a}$ & $29 \pm 1^{b}$ & $50 \pm 6^{c}$ \\
\hline \multicolumn{4}{|l|}{ Vitamins (mg/kg DM) } \\
\hline $\mathrm{A} 1$ & $1.9 \pm 0.1^{b}$ & $0.8 \pm 0.3^{\mathrm{a}}$ & n.d. \\
\hline A2 & n.d. & n.d. & n.d. \\
\hline $\mathrm{C}$ & $553 \pm 137^{b}$ & $617 \pm 10^{b}$ & $94 \pm 54^{\mathrm{a}}$ \\
\hline D3 & $0.7 \pm 0.4$ & $0.3 \pm 0.0$ & n.d. \\
\hline E ( $\alpha$-tokoferol.) & $333 \pm 45^{b}$ & $280 \pm 5^{b}$ & $105 \pm 2^{\mathrm{a}}$ \\
\hline $\mathrm{K}$ & $0.58 \pm 0.24 \mathrm{ab}$ & $1.59 \pm 0.52^{b}$ & $0.21 \pm 0.11^{\mathrm{a}}$ \\
\hline \multicolumn{4}{|l|}{ Carotenoids (mg/kg DM) } \\
\hline Canthaxanthin & $32 \pm 4^{b}$ & $86 \pm 28^{c}$ & $10 \pm 1^{\mathrm{a}}$ \\
\hline Astaxanthin & $11.1 \pm 1.0^{\mathrm{a}}$ & n.d. & $141 \pm 15^{b}$ \\
\hline \multicolumn{4}{|l|}{ Minerals (mg/kg DM) } \\
\hline Iodine & $2.6 \pm 0.8^{a}$ & $3.9 \pm 0.9^{\mathrm{a}}$ & $35 \pm 13^{b}$ \\
\hline Manganese & $6.9 \pm 0.6$ & $3.4 \pm 0.7$ & $6.5 \pm 2.9$ \\
\hline Copper & $10.6 \pm 0.6^{\mathrm{b}}$ & $9.5 \pm 0.7 \mathrm{ab}$ & $8.4 \pm 1.0^{\mathrm{a}}$ \\
\hline Zinc & $41 \pm 6^{\mathrm{a}}$ & $120 \pm 14^{b}$ & $517 \pm 75^{c}$ \\
\hline Selenium & $2.1 \pm 0.1^{b}$ & $1.4 \pm 0.1^{\mathrm{a}}$ & $1.9 \pm 0.3^{\mathrm{ab}}$ \\
\hline \multicolumn{4}{|l|}{ Lipids } \\
\hline 20:4n-6 ARA ( $\%$ TFA) & $1.9 \pm 0.1^{\mathrm{c}}$ & $2.4 \pm 0.0^{\mathrm{b}}$ & $0.6 \pm 0.1^{\mathrm{a}}$ \\
\hline 20:5n-3 EPA (\% TFA) & $4.4 \pm 0.2^{\mathrm{a}}$ & $4.1 \pm 0.3^{\mathrm{a}}$ & $10.8 \pm 1.9^{b}$ \\
\hline $22: 6 n-3$ DHA (\% TFA) & $32 \pm 3^{a}$ & $19 \pm 3^{b}$ & $22 \pm 4^{\mathrm{ab}}$ \\
\hline EPA/ARA & 2.3 & 1.7 & 18.0 \\
\hline Sum fatty acids (mg/g DM) & $98 \pm 18$ & $116 \pm 15$ & $95 \pm 39$ \\
\hline Sum PL $(\%$ TL) & $22 \pm 2^{\mathrm{a}}$ & $25 \pm 0$ ab & $29 \pm 2^{b}$ \\
\hline
\end{tabular}




\begin{tabular}{|c|c|c|c|c|}
\hline B & Rotifers & Artemia & $\begin{array}{c}\text { Small } \\
\text { copepods }\end{array}$ & $\begin{array}{c}\text { Large } \\
\text { copepods }\end{array}$ \\
\hline Dry matter (DM, g/100 g) & $12 \pm 2$ & 5.11 & $13 \pm 2$ & $14 \pm 1$ \\
\hline Protein (g/100 g DM) & $38 \pm 3^{a}$ & 55 & $58 \pm 3^{b}$ & $67 \pm 3 \mathrm{~b}$ \\
\hline Taurine ( $\mu \mathrm{mol} / \mathrm{g} \mathrm{DM})$ & $0.7 \pm 0.0^{\mathrm{a}}$ & 40 & $59 \pm 0^{b}$ & $63 \pm 4^{b}$ \\
\hline \multicolumn{5}{|l|}{ Vitamins (mg/kg DM) } \\
\hline Thiamine & $17.5 \pm 4.7^{b}$ & n.d. & $5.0 \pm 1.3^{\mathrm{a}}$ & $4.7 \pm 1.6^{\mathrm{a}}$ \\
\hline $\mathrm{C}$ & $112 \pm 104$ & 142 & $144 \pm 17$ & $72 \pm 39$ \\
\hline A1 & n.d. & n.d. & n.d. & n.d. \\
\hline $\mathrm{A} 2$ & n.d. & n.d. & n.d. & n.d. \\
\hline D3 & $0.20 \pm 0.02$ & 0.39 & n.d. & n.d. \\
\hline E ( $\alpha$-tokoferol.) & $671 \pm 159^{b}$ & 802 & $58 \pm 23^{\text {a }}$ & $84 \pm 24^{a}$ \\
\hline \multicolumn{5}{|l|}{ Minerals (mg/kg DM) } \\
\hline Iodine & $1.1 \pm 0.2^{\mathrm{a}}$ & 2.2 & $45 \pm 9^{c}$ & $19 \pm 5^{b}$ \\
\hline Manganese & $7.5 \pm 0.6$ & 3.5 & $93 \pm 45$ & $17 \pm 4$ \\
\hline Copper & $15 \pm 3$ & 14.5 & $28 \pm 24$ & $17 \pm 4$ \\
\hline Zinc & $52 \pm 7$ a & 157 & $413 \pm 60 \mathrm{ab}$ & $714 \pm 160^{b}$ \\
\hline Selenium & $0.41 \pm 0.19^{\mathrm{a}}$ & 2.7 & $2.9 \pm 0.5^{b}$ & $4.1 \pm 0.3^{b}$ \\
\hline \multicolumn{5}{|l|}{ Lipids } \\
\hline 20:4n-6 ARA (\% TFA) & $2.0 \pm 0.1^{\mathrm{b}}$ & 2.9 & $0.7 \pm 0.1^{\mathrm{a}}$ & $0.6 \pm 0.3^{\mathrm{a}}$ \\
\hline 20:5n-3 EPA (\% TFA) & $5.0 \pm 0.0^{\mathrm{a}}$ & 5.1 & $17 \pm 3^{b}$ & $19.7 \pm 0.4^{b}$ \\
\hline 22:6n-3 DHA (\% TFA) & $33 \pm 1$ & 9.1 & $35 \pm 3$ & $36 \pm 2$ \\
\hline EPA/ARA & 2.5 & 1.8 & 24.3 & 32.8 \\
\hline Fatty acids (mg/g DM) & $197 \pm 16^{b}$ & 169 & $40 \pm 2^{\mathrm{a}}$ & $47 \pm 2^{\mathrm{a}}$ \\
\hline Sum PL (\% TL) & $24 \pm 2^{\mathrm{a}}$ & 30 & $51 \pm 7^{b}$ & $55 \pm 5^{b}$ \\
\hline
\end{tabular}




\section{Table 5 (on next page)}

Proportion ofzooplanktonin in analysed food

Table 5. Proportion of zooplankton included in the analysis of live food in Exp-2. 
2

\begin{tabular}{cccccccc}
\hline $\begin{array}{c}\text { Dph/ } \\
\text { Sampling } \\
\text { date }\end{array}$ & Fraction & $\begin{array}{c}\text { Copepod } \\
\text { nauplii } \\
\%\end{array}$ & $\begin{array}{c}\text { Juvenile } \\
\text { +adult } \\
\text { copepods } \\
\%\end{array}$ & $\begin{array}{c}\text { Mussel } \\
\text { larvae } \\
\%\end{array}$ & $\begin{array}{c}\text { Polychaete } \\
\text { larvae } \\
\%\end{array}$ & $\begin{array}{c}\text { Mean } \\
\text { DW/ind }\end{array}$ \\
\hline Small & $-5 / 13.04$ & $80-150$ & 98 & 2 & 0 & 0 & 10 \\
& $6 / 26.04$ & $80-150$ & 87 & 10 & 3 & 0 & 7 \\
& $21 / 9.05$ & $80-150$ & 53 & 5 & 34 & 8 & 9 \\
Large & $-5 / 13.04$ & $150-180$ & 64 & 36 & 0 & 0 & 7 \\
& $6 / 26.04$ & $180-250$ & 0 & 100 & 0 & 0 & 30 \\
& $21 / 9.05$ & $180-250$ & 0 & 100 & 0 & 0 & 17 \\
\hline
\end{tabular}

\section{3}

4

5

6 


\section{Table 6(on next page)}

Nutrient levels in cod larvae

Table 6. Exp-1: Levels of selected nutrients in cod larvae sampled at Stages 3 and 5. The group "Rotifers" were larvae first fed with rotifers and then after sampling at stage 3 the larvae were fed Artemia. Larvae in both groups were weaned to dry feed after sampling at stage 4 . Mean $\pm S D, n=3$ tanks, superscripts in rows within each developmental stage indicate significant differences (t-test $p<0.05$ ). 


\begin{tabular}{|c|c|c|c|c|}
\hline \multirow{2}{*}{$\begin{array}{l}\text { Larval stage } \\
\text { Group }\end{array}$} & \multicolumn{2}{|c|}{3} & \multicolumn{2}{|c|}{5} \\
\hline & Rotifers & Copepod & Rotifers & Copepod \\
\hline Age (dph)/Length (mm) & $30 / 8.5$ & $28 / 10.1$ & $71 / 26.5$ & $52 / 23.8$ \\
\hline Feed at sampling & Rotifers & Copepods & Dry feed & Dry feed \\
\hline Dry matter (DM, g/100 g) & $32 \pm 3$ & $29 \pm 3$ & $26 \pm 1$ & $24 \pm 1$ \\
\hline Protein $(g / 100$ g DM) & $70 \pm 1$ & $71 \pm 1$ & $67 \pm 2$ & $67 \pm 2$ \\
\hline Taurine $(\mu \mathrm{mol} / \mathrm{g} \mathrm{DM})$ & $2.1 \pm 0.4^{\mathrm{a}}$ & $40 \pm 5^{\mathrm{b}}$ & $39 \pm 1^{\mathrm{A}}$ & $46 \pm 4^{\mathrm{B}}$ \\
\hline \multicolumn{5}{|l|}{ Vitamins (mg/kg DM) } \\
\hline $\mathrm{A} 1$ & $6.2 \pm 0.8$ & $5.2 \pm 0.8$ & $6.7 \pm 0.8$ & $7.3 \pm 1.4$ \\
\hline $\mathrm{A} 2$ & $0.6 \pm 0.2$ & $0.8 \pm 0.1$ & $1.9 \pm 0.1^{\mathrm{B}}$ & $1.3 \pm 0.1^{\mathrm{A}}$ \\
\hline $\mathrm{C}$ & $368 \pm 52$ & $395 \pm 54$ & $202 \pm 10$ & $192 \pm 9$ \\
\hline D3 & $0.14 \pm 0.00$ & $0.05 \pm 0.03$ & $0.09 \pm 0.02$ & $0.07 \pm 0.03$ \\
\hline E ( $\alpha$-tokoferol.) & $95 \pm 19^{\mathrm{b}}$ & $54 \pm 9^{\mathrm{a}}$ & $103 \pm 5^{\mathrm{B}}$ & $44 \pm 9^{\mathrm{A}}$ \\
\hline $\mathrm{K}$ & $0.13 \pm 0.07$ & $0.04 \pm 0.01$ & $0.18 \pm 0.02^{\mathrm{B}}$ & $0.11 \pm 0.03^{\mathrm{A}}$ \\
\hline \multicolumn{5}{|l|}{ Minerals (mg/kg DM) } \\
\hline Iodine & $0.8 \pm 0.1^{\mathrm{a}}$ & $2.0 \pm 0.6^{\mathrm{b}}$ & $1.7 \pm 0.3$ & $2.7 \pm 1.0$ \\
\hline Manganese & $3.9 \pm 0.3^{b}$ & $2.1 \pm 0.1^{\mathrm{a}}$ & $5.7 \pm 0.8$ & $5.0 \pm 0.3$ \\
\hline Copper & $8.4 \pm 0.5^{\mathrm{b}}$ & $2.9 \pm 0.2^{\mathrm{a}}$ & $3.0 \pm 0.2$ & $3.2 \pm 0.3$ \\
\hline Zinc & $117 \pm 6$ & $120 \pm 0$ & $89 \pm 4$ & $85 \pm 0$ \\
\hline Selenium & $3.3 \pm 0 .^{\mathrm{b}}$ & $1.1 \pm 0.0^{\mathrm{a}}$ & $1.6 \pm 0.1^{\mathrm{B}}$ & $1.1 \pm 0.0^{\mathrm{A}}$ \\
\hline \multicolumn{5}{|l|}{ Lipids } \\
\hline 20:4n-6 ARA (\% TFA) & $4.6 \pm 0.1^{\mathrm{b}}$ & $1.2 \pm 0.0^{\mathrm{a}}$ & $1.3 \pm 0.0^{\mathrm{B}}$ & $0.9 \pm 0.1^{\mathrm{A}}$ \\
\hline 20:5n-3 EPA (\% TFA) & $4.3 \pm 0.1^{\mathrm{a}}$ & $10.1 \pm 0.1^{\mathrm{b}}$ & $8.8 \pm 0.1$ & $9.0 \pm 0.5$ \\
\hline 22:6n-3 DHA (\% TFA) & $37 \pm 0^{\mathrm{b}}$ & $31 \pm 0^{\mathrm{a}}$ & $20 \pm 0^{\mathrm{A}}$ & $22 \pm 1^{\mathrm{B}}$ \\
\hline EPA/ARA & 0.9 & 8.4 & 6.8 & 10.0 \\
\hline Sum FA (mg/g DM) & $55 \pm 7$ & $65 \pm 9$ & $116 \pm 5^{\mathrm{B}}$ & $95 \pm 8^{\mathrm{A}}$ \\
\hline Sum PL ( $\%$ of TL) & $51 \pm 1$ & $51 \pm 1$ & $37 \pm 1^{\mathrm{A}}$ & $42 \pm 1^{\mathrm{B}}$ \\
\hline
\end{tabular}

